\title{
Okul Öncesi Dönemde Sosyal-Duygusal Gelişimin Desteklenmesi: Piramit Modeli ile illgili Çalışmaların Gözden Geçirilmesi ve Ayrıntılı Bibliyografisi*
}

\author{
Sinan KALKAN ${ }^{1}$, Salih RAKAP ${ }^{2}$
}

\begin{abstract}
Öz: Sosyal-duygusal gelişimin çocukların genel gelişimleri ve ileriki yaşamları üzerinde etkilerini ortaya koyan araştırma bulguları, bilim insanlarını okul öncesi dönemdeki çocukların sosyal-duygusal gelişimini desteklemeye yönelik önleyici ve iyileştirici müdahale programları geliştirmeye yöneltmiştir. Bu çalışma, okul öncesi yaş grubundaki çocukların sosyalduygusal gelişimlerini desteklemek amacıyla Piramit Modeli temel alınarak geliştirilen mesleki gelişim programlarının etkililiğinin incelendiği deneysel araştırmalar ile öğretmenlerin bu model kapsamında yer alan stratejileri kullanma düzeylerini inceleyen betimsel çalışmaları gözden geçirmeyi ve ayrıntılı bibliyografisini oluşturmayı amaçlamaktadır. Bu bağlamda alanyazındaki ilgili araştırmaların belirlenmesi için kapsamlı ve sistematik bir kaynak taraması gerçekleştirilmiş ve dâhil etme ölçütlerini karşılayan 10 araştırmaya ulaşılmıştır. Araştırmalar, geliştirilen kodlama formları kullanılarak belirlenen değişkenler ışığında özetlenmiştir. Bu çalışmanın bulguları öğretmenler için geliştirilen, bilimsel dayanaklı olan ya da etkililiği araştırmalar tarafından kanıtlanmış yöntem ve stratejilerin öğretilmesini amaçlayan mesleki gelişim programlarının etkili olabilmesinin, bu programların planlanmasında ve sunulmasında etkili yaklaşımların tercih edilmesiyle yakından ilişkili olduğunu göstermektedir.
\end{abstract}

Anahtar Sözcükler: Piramit Modeli, Sosyal-Duygusal Gelişim, Problem Davranış, Mesleki Gelişim, Erken Müdahale

\section{Supporting Social-Emotional Development in Preschool: A Review and Annotated Bibliography of Pyramid Model Studies}

\begin{abstract}
Research findings revealing the effects of social-emotional development on general development of children have led scientists to develop preventive and remedial intervention programs to support social-emotional development of young children. The purpose of this study was to conduct a review and annotated bibliography of experimental studies investigating impact of professional development (PD) focused on Pyramid Model practices and descriptive studies examining preschool teachers' use of Pyramid Model practices. A systematic review of the literature was conducted to identify relevant studies; 10 studies (6 experimental and 4 descriptive) met the inclusion criteria and included in the current study. These studies were coded and summarized using investigator-developed coding forms. Findings show that the success of PD programs developed to train teachers on evidence-based practices is closely linked with how these programs are developed and delivered to teachers. In order to be effective, PD programs should use evidence-based and effective training practices.
\end{abstract}

Keywords: Pyramid Model, Social-Emotional Development, Challenging Behavior, Problem Behavior, Professional Development, Early Intervention 
Okul öncesi dönem, çocukların sonraki öğrenmelerine temel oluşturan becerilerin kazanıldığ hızlı olduğu kritik bir dönemdir. Bu dönemde çocukların gelişimi, fiziksel, bilişsel, dil ve konuşma ile sosyalduygusal gelişim olmak üzere dört temel alanda ele alınmaktadır (Senemoğlu, 2018). Çocukların diğer alanlardaki gelişimlerini önemli düzeyde etkileyen ve destekleyen sosyal-duygusal gelişim, bireyin toplumsal uyumunu arttıracak sosyal becerileri, kendini yönetme ve problem çözme becerilerini, başkalarının duygularını anlama ve onlara uygun tepkide bulunma gibi becerileri kapsamaktadır (Fox, Hemmeter, Snyder, Binder ve Clarke, 2011; Meadan ve Jegatheesan, 2010; Ocak ve Arda, 2014; Ostrosky ve Meadan, 2010). Alanyazında, çocukların çoğu problem davranışlarının altında yatan temel nedenin sosyal ve duygusal becerilerdeki sınırlılıklar ya da yetersizlikler olduğu belirtilmektedir (Fox, Dunlap, Hemmeter, Joseph ve Strain, 2003; Gizir, 2002; Hemmeter, Fox ve Snyder, 2013). Araştırmalar, erken çocukluk döneminde sosyalduygusal gelişimi destekleme bağlamında yaşanan sınırlılıkların ve önlenmeyen ya da ortadan kaldırılmayan davranış problemlerinin ilerleyen yıllarda çocukların hem akademik başarılarını hem de sosyal yaşantılarını olumsuz yönde etkilediğini ve okulu bırakma, artan oranda suça karışma gibi başka birçok ciddi soruna temel oluşturduğunu göstermektedir (Cristóvão, Candeias ve Verdasca, 2017; Duncan ve Magnuson, 2011; ParlakRakap, 2011; Waltz, 2013).

Sosyal-duygusal gelişimin çocukların genel gelişimleri ve ileriki yaşamları üzerinde etkilerine ilişkin araştırma bulguları, bilim insanlarını okul öncesi yaş grubundaki çocukların sosyal-duygusal gelişimini desteklemeye ve problem davranışlarını önlemeye yönelik önleyici ve iyileştirici müdahale programları geliştirmeye yöneltmiştir (Hollingsworth ve Winter, 2013). Bu bağlamda geliştirilen stratejilerin büyük çoğunluğu, geleneksel olarak uygulamalı davranış analizine dayalı, problem davranışlar ortaya çıtıktan sonra çözüm bulmaya odaklı, başka bir deyişle, sonuçları değiştirmeye ya da uyarlamaya yönelik uygulamalardır (Bambara ve Kern, 2005; Sailor, Dunlap, Sugai ve Horner, 2009). Ancak, okul öncesi dönemde problem davranışlarla başa çıkma amacıyla geliştirilen müdahale programlarının hem önleyici hem de iyileştirici strateji ve bileşenleri içermesi, müdahalelerin etkililiği bağlamında oldukça önemlidir (Durlak ve DuPre, 2008; Ocak, 2011; Ocak ve Arda, 2014; Webster-Stratton ve Reid, 2003). Bu bileşenler göz önünde bulundurularak geliştirilen, etkililiği deneysel araştırmalar yoluyla incelenen ve yaygın bir şekilde kullanılan önleyici ve iyileştirici programlardan biri de Piramit Modelidir (Fox ve Hemmeter, 2009; Hemmeter, Ostrosky ve Fox, 2006).

Küçük çocuklarda sosyal-duygusal gelişimi desteklemek ve problem davranışları önlemek amacıyla geliştirilen Piramit Modeli, dört düzeyden oluşan kanıta dayalı uygulamaların üç aşamalı (evrensel destek, önleme ve müdahale) kavramsal çerçevesini sunmaktadır (Artman-Meeker, 2010; Fox ve diğerleri, 2011). Piramit Modeli, belirli bir müfredatı takip etmekten ziyade mevcut müfredat uygulamaları için bir çerçeve oluşturmaktadır (Hemmeter ve diğerleri, 2013). Piramit Modeli'nin diğer çerçeve programlara göre en önemli özelliği, spesifik olarak küçük çocukların sosyal-duygusal gelişimini desteklemeye ve problem davranışlarını önlemeye odaklanmış olmasıdır (Fox ve diğerleri, 2011; Hemmeter, Hardy, Schnitz, Adams ve Kinder, 2015; Meadan ve Jegathean, 2010; Ostrosky ve Meadan, 2010). Modelde kullanılan önleyici stratejiler, problem davranışların ortaya çıkma olasılıklarıyla ilgili üç varsayıma dayanmaktadır. Buna göre, çocuklar kendileri için gelişimsel olarak uygun materyal ve etkinlikler belirlenmediğinde, ne yapacaklarını bilmediklerinde, öğretmenin davranış beklentilerini anlamadıklarında ve gelişimsel açıdan uygun ve etkili iletişim stratejilerine sahip olmadıklarında daha sık davranış problemleri sergilemektedirler (Hemmeter ve diğerleri, 2006).

Öğrenme Piramidi olarak da adlandırılan Piramit Modeli Şekil 1'de görüldüğü gibi genelden özele doğru Birincil Evrensel Destek, İkincil Önleme ve Üçüncül Müdahale aşamalarından oluşmaktadır. Evrensel Destek aşaması, Destekleyici İlişkiler ve Yüksek Kaliteli Çevresel Destek düzeylerinden oluşurken, İkincil Önleme aşaması Hedeflenen Sosyal-Duygusal Destekler düzeyinden ve Üçüncül Müdahale aşaması ise Yoğun Müdahale düzeyinden oluşmaktadır (Fox ve diğerleri, 2011; Ostrosky ve Meadan, 2010). Öğrenme Piramidi kapsamında yer alan aşamaların başarılı bir şekilde uygulanması, temel düzeyde etkili bir iş günün oluşturulmasıyla doğrudan ilişkilidir. Mevcut sistem ve eğitim politikalarının desteği ile bilimsel dayanaklı uygulamaların kullanımını destekleyen, farklı disiplinler arasında belirli amaçlar doğrultusunda iş birliği yapmayı önemseyen ve ebeveynler ile iş birliğinin önemine inanan etkili bir iş gücünün var olduğu yapılarda 
Piramit Modeli temelinde geliştirilen müdahale programlarının daha etkili olacağ düş̧ünülmektedir (Fox ve diğerleri, 2011; Meadan ve Jegatheesan, 2010; Ostrosky ve Meadan, 2010).

Piramidin Birincil Evrensel Destek Aşaması, sadece problem davranış sergileyen çocukları değil, tüm çocukları kapsayacak uygulamaları içermektedir. Bu aşama, destekleyici ilişkiler ve yüksek kaliteli çevresel destek olmak üzere iki düzeyden oluşmaktadır. Çocuklarda sosyal-duygusal becerilerin geliştirilmesinde ilişkiler önemlidir. Güvenli ilişkiler, çocukların çevrelerindeki kişilerin davranışlarına nasıl tepki vereceklerini öğrenmelerine ve kendi davranışlarının çevreyi nasıl etkilediğini anlamalarına fırsat sunmaktadır (Richardson-Gibbs ve Klein, 2014; Fullerton, Conroy ve Correa, 2009; Hemmeter ve diğerleri, 2006; Lynch ve Simpson, 2010). Çocukların sosyal ve duygusal gelişimi için besleyici, uyarıcı, teşvik edici, yüksek kaliteli ve destekleyici ortamlar gereklidir (Richardson-Gibbs ve Klein, 2014; Lynch ve Simpson, 2010). Bu aşamada, çocukların öğrenme süreçlerini ve etkinliklere katılımını destekleyen çevresel düzenlemeler ile öğretmenlerin çocuklarla olumlu iletişime girmesi, çocukların konuşma isteklerine olumlu karşlık vermesi, çocukların uygun davranışlarına olumlu betimsel geribildirimler vermesi ve destekleyici etkileşimler kurması teşvik edilir (Fox ve diğerleri, 2003; Hemmeter ve diğerleri, 2013; Hemmeter ve Fox, 2009). Bu bağlamda Evrensel Destek Aşaması, çocukları öğrenmeye teşvik eden yüksek kaliteli ortamları geliştirmeyi, sınıf kurallarını ve davranış beklentilerini öğretmeyi, etkinlikler arası geçişleri yapılandırmayı, öğretmen ve çocuk merkezli etkinlikler arasında denge kurmayı, günlük etkinlik ve rutinleri belirlemeyi destekleyen stratejileri içerir (Lynch \& Simpson, 2010; Meadan \& Jegatheesan, 2010).

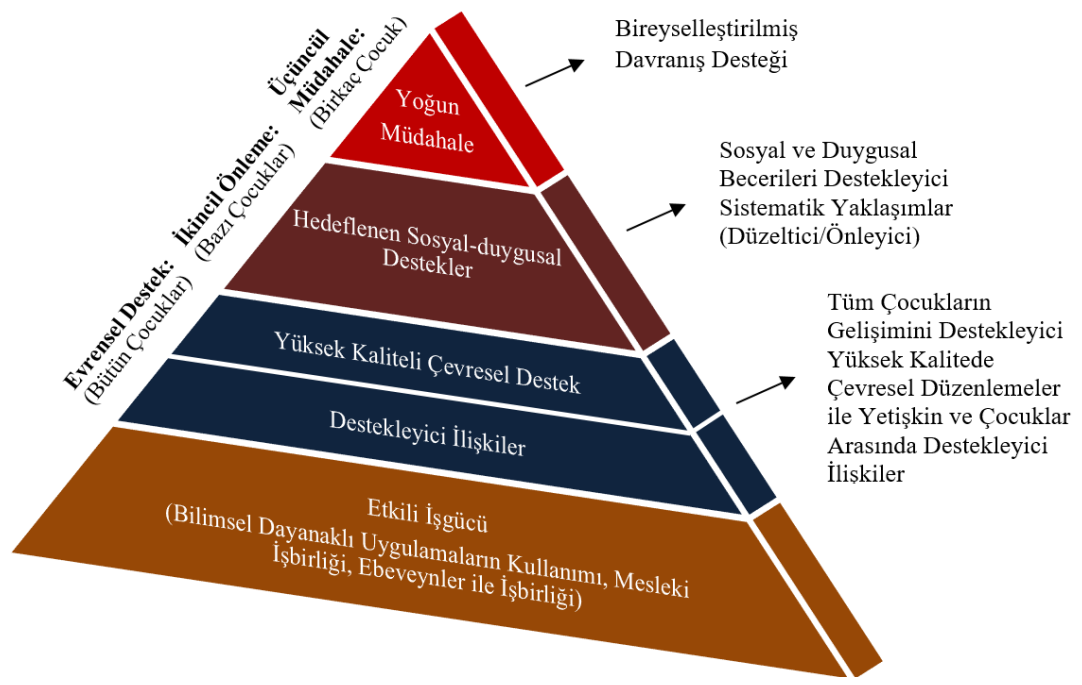

Şekil 1. Sosyal-duygusal öğrenme piramidi (Fox ve diğerleri, 2003).

Piramidinin İkincil Önleme Aşaması, evrensel düzeyde sağlanan destekleyici olumlu ilişkilere ve yüksek kaliteli çevresel desteğe rağmen, sosyal-duygusal becerilerin geliştirilmesi bağlamında sorun yaşayan ve problem davranışlar sergileyen çocuklara küçük gruplar halinde sunulan desteği içermektedir. Bu aşama birçok farklı öğretim stratejisinden oluşmaktadır. İkincil Önleme Aşamasında, sosyal-duygusal gelişiminde gecikme riski olan çocuklara, birinci aşamada sağlanan yapısal desteklerin yanında sosyal beceri, özdenetim, duygusal farkındalık geliştirme (duyguları anlama ve uygun tepkiden bulunma), arkadaşlık becerileri ve problem çözme gibi konularda küçük gruplar halinde öğretim yapılır (Fox ve diğerleri, 2011; Meadan ve Jegatheesan, 2010; Ostrosky ve Meadan, 2010).

Piramidin Üçüncül Müdahale Aşaması, birincil evrensel ve ikincil önleme aşamalarında gerçekleştirilen müdahalelere cevap vermeyen çocuklar için bireyselleştirilmiş kapsamlı müdahalelerin sunulduğu aşamadır. Yoğun müdahaleler, tekrar eden problem davranışlara ve sosyal-duygusal becerilerde yüksek düzeyde sinırlılığa sahip olan çocuklar için tasarlanmıştır (Fox ve diğerleri, 2011). Üçüncül Müdahale Aşamasında yoğun desteğe ihtiyaç duyan (ağır düzeyde problem davranış sergileyen ve sosyal-duygusal yönden önemli 
düzeyde yetersizlik gösteren) çocuklar için, sosyal-duygusal yetkinliklere yönelik eğitim, genellikle bireysel olarak daha belirgin bir şekilde sunulur ve çocuktaki ilerlemeler daha sık takip edilir (Fox ve diğerleri, 2011; Ostrosky ve Meadan, 2010). Bu aşamada, bireyselleştirilmiş müdahale sunulan çocuklar için evrensel ve ikincil önleme aşamalarındaki destekler devam ettirilir.

Bu çalışma, okul öncesi dönemdeki çocukların sosyal-duygusal gelişimlerini desteklemek ve problem davranışlarını önlemek amacıyla Piramit Modeli temel alınarak geliştirilen müdahale programlarının etkililiğinin incelendiği deneysel çalışmalar ile öğretmenlerin Piramit Modeli kapsamında yer alan stratejileri kullanma düzeylerini inceleyen betimsel çalışmaları gözden geçirmeyi ve ayrıntılı bibliyografisini sunmayı amaçlamaktadır. Alanyazında Piramit Modelini tanıtan, modelin bileşenlerini ele alan, model kapsamındaki stratejilerin kullanım düzeylerini inceleyen betimsel çalışmalar (Heo, Cheatham, Hemmeter ve Noh, 2014; Luo, Snyder, Clark ve Hong, 2017; Rakap, Balikci, Kalkan ve Aydin, 2018; Steed ve Roach, 2017) ile bu model temelinde geliştirilen müdahale programlarının etkililiğini inceleyen deneysel araştırmalar (Fettig ve ArtmanMeeker, 2016; Hemmeter, Snyder, Fox ve Algina, 2016; Lam ve Wong, 2017) bulunmasına karşın deneysel ve betimsel çalışmaları farklı değişkenler bağlamında inceleyen bir alanyazın taraması bulunmamaktadır. Bu alanyazın taraması ve ayrıntılı bibliyografya bağlamında Piramit Modelini temel alan deneysel ve betimsel araştırmaların ve özelliklerinin incelenmesinin ilerleyen dönemlerde bu alanda yapılacak çalışmalar için yol gösterici nitelikte olduğu düşünülmektedir. Ayrıca, bu çalışmada ele alınan araştırmaların Türkiye'de görev yapan okul öncesi öğretmenlerin mesleki gelişimlerinin desteklenmesine yol göstermesi beklenmektedir. Dahası, bu çalışmada yer verilen araştırmaların mesleki gelişim programlarının etkililiği ile bu programların planlanmasında ve sunulmasında etkili yaklaşımların hangileri olduğuna dair alanyazındaki tartışmalar ile bu yönde geliştirilecek müdahale programlarına katkı sağlayacağı öngörülmektedir.

\section{Yöntem}

\section{Araştırma Modeli}

Okul öncesi dönemdeki çocukların sosyal-duygusal gelişimlerini desteklemek ve problem davranışlarını önlemek amacıyla Piramit Modeli temel alınarak geliştirilen müdahale programlarının etkililiğinin ve öğretmenler tarafından kullanım düzeylerinin incelendiği bu çalışmada, ilişkisel tarama modeli kullanılmış olup araştırma kapsamında ele alınan deneysel ve betimsel araştırmaların ayrıntılı bibliyografisi (Annotated Bibliography) sunulmuştur. Ayrıntılı bibliyografi, okuyucuya girdilerin veya her bir kaynağın özetini veren ve değerlendirmesini sağlayan bir kaynakça olarak tanımlanmaktadır (Knott, 2004).

\section{Çalışmaların Belirlenmesi}

Alanyazındaki ilgili araştırmaların belirlenmesi için kapsamlı ve sistematik bir kaynak taraması yapılmıştır. Kaynak taraması, Ondokuz Mayıs Üniversitesi kütüphanesinin abone olduğu elektronik veri tabanlarında (Complementary Index, Education Source, Academic Search Complete, MasterFILE Complete, ScienceDirect, eBook Index, ERIC, Social Sciences Citation Index, Scopus ${ }^{\circledR}$, ULAKBIM Turkish National Databases, Expanded Academic ASAP, Academic OneFile, Emerald Insight, General OneFile, Supplemental Index, Research Starters, Business Source Complete, Teacher Reference Center ve JSTOR Journals) arama yapılarak 01.09.2018 tarihinde gerçekleştirilmiştir. Veri tabanlarında arama yapılırken "Teaching Pyramid", "Pyramid Model", "preschool, and young child" terimleri İngilizce ve Türkçe olarak farklı kombinasyonlarda kullanılmıştır. Elektronik ortamda yapılan taramada toplam 174 çalışmaya erişilmiştir. Yinelenen sonuçlar çıarıldıktan sonra geriye 121 makale kalmış ve bu 121 makalenin özetleri ve gerekli olan durumlarda tamamı dâhil etme ölçütleri kullanılarak incelenmiştir.

\section{Dâhil Etme ve Hariç Tutma Kriterleri}

$\mathrm{Bu}$ çalışma kapsamında erişilen araştırmaların ayrıntılı bibliyografide yer alıp almayacağını belirlemek amacıyla dört dâhil etme ve altı hariç tutma ölçütü geliştirilmiş ve 121 makale bu ölçütler doğrultusunda incelenmiştir. Dâhil etme ölçütleri, (a) makalenin hakemli bilimsel bir dergide yayımlanmış olmasını, (b) makalenin Türkçe/İngilizce özetlerinin erişilebilir olmasını, (c) makalenin bir deneysel ya da yarı deneysel desen kullanan araştırma çalışması ya da Piramit Modeli stratejilerinin kullanımını inceleyen betimsel bir 
araştırma çalışması rapor etmesini ve (d) çalışma kapsamında uygulayıcı olarak okul öncesi ya da özel eğitim öğretmenlerinin yer almış olmasını içermektedir. Bu çalışmada (a) araştırmanın hakemli bilimsel bir dergide yayımlanmaması, (b) Türkçe ya da İngilizce özetlerine erişilememesi, (c) araştırmanın kitap, derleme, metaanaliz vb. türünde olması, (d) katılımcılarının okul öncesi ve özel eğitim öğretmenleri dışında olması, (e) araştırmanın yayımlanmamış olması ve (f) araştırmanın konuyla doğrudan ilişkili olmayan ikincil kaynaklarda yayımlanması hariç tutma ölçütleri olarak belirlenmiştir.

\section{Araştırmaların Gözden Geçirilmesi ve Kodlanması}

Dâhil etme ölçütleri kullanılarak makaleler incelendiğinde 121 çalışmadan 10 tanesinin (6 deneysel araştırma ve 4 betimsel araştırma) tüm ölçütleri karşıladığı, 111 tanesinin ise en az bir dâhil etme ölçütünü karşılamadığı belirlenmiştir. Dâhil etme ölçütlerini karşılayan 10 makalenin kaynakçaları olası başka çalışmaların belirlenmesi amacıyla gözden geçirilmiş; bu bağlamda toplam 12 ek makale dâhil etme ölçütleri kullanılarak değerlendirilmiş ve bu çalışmalardan hiçbirinin tüm dâhil etme ölçütlerini karşılamadığ tespit edilmiştir. Sonuç olarak, 133 makale dâhil etme ölçütleri doğrultusunda incelenmiş ve üçü grup deneysel ve üçü de tek denekli deneysel araştırma desenlerini kullanan altı deneysel çalışma ile dört betimsel çalışma sistematik derleme ve ayrıntılı bibliyografya çalışmasına dâhil edilmiştir. Bu 10 çalışma araştırmacılar tarafından deneysel ve betimsel araştırmaların özetlenmesi için geliştirilen iki farklı kodlama formu kullanılarak özetlenmiştir. Deneysel araştırmaların özetlenmesi amacıyla geliştirilen kodlama formunda araştırmacılar incelenen araştırmaları, araştırmanın yöntemi, araştırmanın katılımcıları, araştırmanın bağımlı ve bağımsız değişkenleri, araştırmanın uygulama süresi ve uygulama güvenirliği gibi değişkenler açısından incelemişlerdir. Bu bağlamda kodlama formundaki değişkenler incelenen araştırmalarda var ise (1), yok ise (0) şeklinde araştırmacılar tarafından kodlanmıştır. Betimsel araştırmaların özetlenmesi de benzer şekilde amaç, katılımcılar ve veri toplama araçları gibi değişkenler dikkate alınarak kodlanmıştır.

Elektronik veri tabanı aramaları ve kaynakçaların gözden geçirilmesi sonucu elde edilen toplam 133 makalenin incelenmesi ve dâhil edilme ölçütlerini karşılayan 10 çalışmanın kodlanması işlemlerinin güvenirliğini belirlemek üzere 133 makaleden 44 tanesi (\%33) ve 10 makalenin tamamı (\%100) ikinci bir değerlendirici tarafından incelenmiş ve kodlanmıştır. Her iki değerlendiricinin yapmış olduğu inceleme ve kodlama sonuçları karşılaştırılarak değerlendiriciler arası güvenirlik katsayısı hesaplanmıştır. Bu bağlamda, değerlendiriciler arası güvenirlik katsayıları sırasıyla \%100 ve \%98 olarak bulunmuştur.

\section{Bulgular}

Bu çalışmaya dahil edilen araştırmaların ayrıntılı bibliyografisi, (a) grup deneysel araştırmalar, (b) tek denekli deneysel araştırmalar ve (c) betimsel araştırmalar olmak üzere üç bölümde sunulmuştur.

\section{Bölüm I: Grup Desenli Deneysel Araştırmalar}

Yapılan alanyazın taraması sonucunda Piramit Modelini temel alan müdahale programlarının etkililiğini inceleyen, ikisi Amerika Birleşik Devletleri'nde (ABD) biri de Hong Kong'da gerçekleştirilen üç grup desenli deneysel araştırmaya ulaşılmıştır (Fettig ve Artman-Meeker, 2016; Hemmeter ve diğerleri, 2016; Lam ve Wong, 2017). Bu çalı̧̧malara ilişkin, katılımcı sayıları, araştırma yöntemi, bağımlı ve bağımsız değişkenler, uygulama süresi, uygulama güvenirliği verileri ve bulgular Tablo 1'de sunulurken her bir çalışmanın ayrıntılı bibliyografisi çalışmaların yayınlandığı yıla göre en eskiden en yeniye doğru aşağıda sunulmuştur.

Hemmeter, M. L., Snyder, P. A., Fox, L., \& Algina, J. (2016). Evaluating the implementation of the Pyramid Model for promoting social-emotional competence in early childhood classrooms. Topics in Early Childhood Special Education, 36(3), 133-146.

Hemmeter ve diğerleri (2016) tarafından gerçekleştirilen çalışmada, öğretmenlerin eğitim çalıştayları ve koçluk içeren bir mesleki gelişim programı desteği ile sınıf içinde kullandıkları Piramit Modeli stratejilerinin, çocukların sosyal-duygusal becerileri ve problem davranışları üzerindeki etkileri, randomize kontrollü deneysel desen kullanılarak incelenmiştir. Araştırmanın bağımlı değişkeni, öğretmenlerin sınıf etkinlikleri ve rutinleri bağlamında Piramit Modeli stratejilerini uygulama düzeyleri ile çocukların sosyal-duygusal becerileri ve problem davranışlarındaki değişimdir. Araştırmanın bağımsız değişkeni ise öğretmen eğitim 
çalıştayları ve uygulama temelli koçluk desteğinden oluşan mesleki gelişim programıdır. Araştırma, ABD'de iki farklı eyalette devlet tarafından desteklenen, özel gereksinimli ve normal gelişim gösteren çocukların devam ettiği okul öncesi sınıflarında yürütülmüştür. Araştırmaya, deney $(n=20)$ ve kontrol $(n=20)$ gruplarında yer alan toplam 40 okul öncesi öğretmeni ile sinıflarında yer alan toplam 494 çocuk (Deney=252; Kontrol=242) katılmıştır. Araştırmaya dâhil olan katılımcılarının tamamı kadın öğretmenlerden oluşmuştur. Öğretmenlerden 16'sı lisans, 24'ü yüksek lisans düzeyinde eğitim almışlardır. Öğretmenlerin \%62.5'i erken çocukluk eğitimi veya erken çocukluk özel eğitimi alanında bir dereceye sahiptir. Çalışmanın başında, deney grubunda yer alan öğretmenlerin ortalama 7 yll, kontrol grubundaki öğretmenlerin ise ortalama 12 yıl mesleki deneyimi bulunmaktadır. Çalışmaya katılan çocukların ortalama yaşı 4 iken yaklaşık olarak \%70'i bireyselleştirilmiş eğitim programına sahip yetersizlik tanısı almış çocuklardan oluşmaktadır.

Bu çalışma kapsamında, deney grubunda yer alan öğretmenler, Piramit Modeli stratejilerine yönelik farklı günlerde gerçekleştirilen 6.5 saatlik üç ayrı eğitim oturumuna (toplam 19.5 saat) katılmışlardır. Deney grubundaki öğretmenler eğitim sonrasında uygulama temelli bireysel koçluk desteği almışlardır. Koçlar, her bir öğretmenin sınıfında, 12 ile $16(X=13.4)$ hafta boyunca haftada en az bir kez bir gözlem ve bilgilendirme oturumu gerçekleştirmiştir. Araştırmada, öğretmen eğitim programı (çalıştay) ve sınıf içi koçluğa dair uygulama güvenirliği verileri (sırasıyla tüm oturumların $\% 100$ ve \%25'inde) ile veri toplama işlemleri için gözlemciler arası güvenirlik verileri (tüm veri toplama oturumlarını en az \%25'i için) rapor edilmiştir. Çalıştayların uygulama güvenirliği \%97 ile \%98 arasında değişirken uygulama temelli koçluk desteğinin uygulama güvenirliği \%88 (ranj = \%45-\%100) olarak bulunmuştur. Kullanılan tüm gözlem araçları için ortalama gözlemciler arası güvenirlik katsayısı en az \%86 olarak rapor edilmiştir. Araştırmanın bulguları, deney grubundaki öğretmenlerin, kontrol grubundaki öğretmenlere kiyasla Piramit Modeli stratejilerini doğru kullanma bağlamında daha büyük bir gelişme gösterdiklerini ortaya koymuştur. Deney grubundaki öğretmenlerin sınıflarındaki çocuklar ile kontrol grubundaki öğretmenlerin sınıflarındaki çocuklar karşılaştırıldığında ise öğretmenleri deney grubunda yer alan çocukların sosyal etkileşim becerilerinin gelişimi ve problem davranışların azalışı bağlamında daha büyük gelişme gösterdikleri bulunmuştur. Çalışma kapsamında öğretmen uygulamaları için etki büyüklüğü istatistiği hesaplanmazken çocukların sosyal becerilerindeki gelişim için etki büyüklüğü değeri $d=0.32$ olarak rapor edilmiştir.

Fettig, A. \& Artman-Meeker, K. (2016). Group coaching on pre-school teachers' implementation of pyramid model strategies: A program description. Topics in Early Childhood Special Education, 36(3), 147-158.

Bu çalışmada araştırmacılar, grup halinde sunulan koçluk desteğinin okul öncesi öğretmenlerinin Piramit Modeli stratejilerini doğru ve sık kullanmaları üzerindeki etkilerini öntest-sontest deneysel araştırma desenini kullanarak incelemiştir. Araştırmanın bağımlı değişkeni, öğretmenlerin sınıf etkinlikleri ve rutinleri içerisine Piramit Modeli stratejilerini uygulama düzeyleri iken bağımsız değişkeni ise öğretmen eğitimi ve grup olarak sunulan koçluk desteğinden oluşan mesleki gelişim programıdır. Araştırmaya, altı okul öncesi öğretmeni katılmıştır. Öğretmenlerden biri ön lisans, üçü lisans ve ikisi yüksek lisans düzeyinde eğitim almışlardır. Araştırmada yer alan öğretmenlerin 7 ile 25 yıl arasında mesleki deneyimi bulunmaktadır. Çalışmaya katılan öğretmenler, Piramit Modeli kapsamında yer alan stratejilerin anlatıldığ 2 saat uzunluğunda 6 eğitim oturumuna katılmışlardır (toplam 12 saat). Eğitim oturumları 2-3 hafta arayla sunulmuştur. Öğretmenler her eğitim oturumunu takiben ve bir sonraki eğitim oturumundan önce grup olarak yaklaşık 90 dakika uzunluğunda koçluk desteği almışlardır. Bu bağlamda her öğretmen toplamda 10 koçluk oturumuna katılmıştır. Çalışma kapsamında uygulama güvenirliği ve gözlemciler arası güvenirlik verisi rapor edilmemiştir. Öğretmenlerin Piramit Modeli stratejilerini doğru kullanma düzeyleri, Piramit Modeli Gözlem Sistemi (Fox, Hemmeter ve Snyder, 2014) kullanılarak ilk eğitim oturumundan önce (öntest) ve son koçluk oturumundan sonra (sontest) ölçülmüştür. Araştırmanın bulguları, eğitime katılan ve grup koçluğu alan öğretmenlerin Piramit Modeli stratejilerini doğru kullanma düzeylerinde ortalama olarak \%20 civarında bir artış olduğunu göstermiştir. Bu bağlamda, öğretmenler öntest sırasında stratejileri \%43 oranında doğru bir şekilde uygularken sontest sırasında bu oran \%62'ye kadar çıkmıştır. 
Lam, L. T. \& Wong, E. M. (2017). Enhancing social-emotional well-being in young children through improving teachers' social-emotional competence and curriculum design in Hong Kong. International Journal of Child Care and Education Policy, 11(5), 1-14.

Araştırmacılar, küçük çocuklarda sosyal-duygusal gelişimi desteklemek amacıyla Piramit Modeli temel alınarak geliştirilen bir öğretmen eğitim programının anasınıflarına devam eden ve eğitime katılan öğretmenlerin sınıflarında yer alan çocukların sosyal beceri ve problem davranışları üzerindeki etkilerini inceledikleri çalışmada öntest-sontest araştırma desenini kullanmışlardır. Araştırmanın bağımlı değişkenini, çocukların sosyal-duygusal gelişimleri ile problem davranış düzeyleri oluştururken, bağımsız değişkenini ise Piramit Modeli çerçevesinde geliştirilmiş sosyal-duygusal gelişimin desteklenmesine odaklanan öğretmen eğitim programı oluşturmaktadır. Araştırmaya Hong Kong'da 32 devlet anaokulunda görev yapan 106 anasınıfı öğretmeni ve bu öğretmenlerin çalıştı̆̆ı sınıflara devam eden toplam 990 çocuk katılmıştır. Çalışma kapsamında katılımcı öğretmen sayısı dışında, öğretmenler ile ilgili herhangi bir bilgi rapor edilmemiştir. Çalışmaya katılan 990 çocuktan, 505'i erkek, 485'i ise kız çocuktur. Çocukların yaş ortalaması $4.3(S D=1.0)$ iken 87 (\%9) çocuğun gelişimsel bir probleme sahip olduğu rapor edilmiştir.

Çalışma kapsamında öğretmenler iki aylık bir süre içerisinde bir dizi eğitime katılmışlardır. Eğitim oturumları, sözlü sunum, çevrimiçi multimedya çalışmaları, rol oynama, tartışma ve etkileşimli aktiviteler dâhil olmak üzere çoklu öğretim yaklaşımlarıyla harmanlanmış bir dizi interaktif seminerden oluşmaktadır. Eğitimler bağlamında, öğretmenler ile gerçekleştirilen öz-değerlendirme etkinliğinden sonra, duygusal okuryazarlık, iletişim, erken çocukluk döneminde sosyal-duygusal gelişimin desteklenmesine yönelik konular ve stratejiler ele alınmıştır. Araştırmada, uygulanan eğitim programına ilişkin uygulama güvenirliği verisi ile veri toplama işlemleri için gözlemciler arası güvenirlik verileri rapor edilmemiştir. Araştırmanın sonunda, Sosyal Yetkinlik ve Davranış Değerlendirme Ölçeği (LaFreniere ve Dumas, 1996) kullanılarak toplanan öntest ve sontest verileri karşılaştırıldığında, öğretmenlere verilen eğitim ile birlikte çocukların sosyal-duygusal gelişimlerinde istatistiksel olarak anlamlı bir iyileşme olduğu ve müdahaleden sonra çocukların kaygı düzeyleri ile saldırgan davranışlarında önemli bir azalma olduğu görülmüştür. 
Sinan KALKAN \& Salih RAKAP

Tablo 1. Piramit Modelinin Etkililiğini İnceleyen Grup Desenli Deneysel Araştırmalar

\begin{tabular}{|c|c|c|c|c|c|c|c|c|c|c|}
\hline \multirow{2}{*}{ Çalışma } & \multicolumn{2}{|c|}{ Katılımcılar } & \multirow{2}{*}{ Araştırma Yöntemi } & \multirow{2}{*}{ Bağımlı Değiş̧ken } & \multirow[b]{2}{*}{ Bağımsız Değişken } & \multirow{2}{*}{$\begin{array}{l}\text { Uygulama } \\
\text { Süresi }\end{array}$} & \multicolumn{2}{|c|}{ Uygulama Güvenirliği } & \multicolumn{2}{|c|}{ Bulgular } \\
\hline & Öğretmen & Çocuk & & & & & Çalıştay & Koçluk & Öğretmen & Çocuk \\
\hline 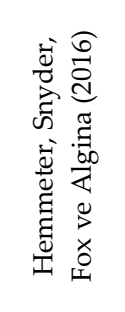 & $\begin{array}{l}40(20 \mathrm{DG} \\
+20 \mathrm{KG})\end{array}$ & $\begin{array}{l}104(56 \mathrm{DG}+ \\
48 \mathrm{KG})\end{array}$ & $\begin{array}{l}\text { Randomize } \\
\text { kontrollü deneysel } \\
\text { desen }\end{array}$ & $\begin{array}{l}\text { Öğretmenlerin Piramit } \\
\text { Modeli stratejilerini } \\
\text { uygulama düzeyleri } \\
\text { ile çocukların sosyal- } \\
\text { duygusal becerileri ve } \\
\text { problem } \\
\text { davranışlarındaki } \\
\text { değişim }\end{array}$ & $\begin{array}{l}\text { Öğgretmen eğitim } \\
\text { çalıştayları ve } \\
\text { uygulama temelli } \\
\text { koçluk desteğinden } \\
\text { oluşan mesleki } \\
\text { gelişim programı }\end{array}$ & $\begin{array}{l}\text { 19,5 saat } \\
\text { öğretmen } \\
\text { eğitimi } \\
\text { 12-16 koçluk } \\
\text { oturumu }\end{array}$ & $\% 97-\% 98$ & $\% 88$ & $\begin{array}{l}\text { Uygulama } \\
\text { düzeyi: Deney } \\
\text { grubu }>\text { Kontrol } \\
\text { grubu }\end{array}$ & $\begin{array}{l}\text { Sosyal etkileşim- } \\
\text { problem davranıs } \\
\text { düzeyindeki } \\
\text { gelişim: } \\
\text { Deney grubu > } \\
\text { Kontrol grubu }\end{array}$ \\
\hline 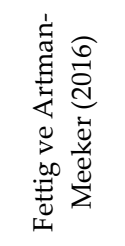 & 6 & - & $\begin{array}{l}\text { Öntest-sontest } \\
\text { araştırma deseni }\end{array}$ & $\begin{array}{l}\text { Öğretmenlerin Piramit } \\
\text { Modeli stratejilerini } \\
\text { uygulama düzeyleri }\end{array}$ & $\begin{array}{l}\text { Öğretmen eğitimi ve } \\
\text { grup olarak sunulan } \\
\text { koçluk desteğinden } \\
\text { oluşan mesleki } \\
\text { gelişim programı }\end{array}$ & $\begin{array}{l}12 \text { saat } \\
\text { öğretmen } \\
\text { eğitimi } \\
10 \text { koçluk } \\
\text { oturumu }\end{array}$ & - & - & $\begin{array}{l}\text { Piramit Modeli } \\
\text { stratejilerini } \\
\text { doğru kullanma } \\
\text { düzeyinde } \\
\text { ortalama \%20 } \\
\text { artış }\end{array}$ & \\
\hline 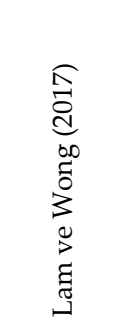 & 106 & 990 & $\begin{array}{l}\text { Öntest-sontest } \\
\text { araştırma deseni }\end{array}$ & $\begin{array}{l}\text { Çocukların sosyal- } \\
\text { duygusal gelişimleri } \\
\text { ile problem davranış } \\
\text { düzeyleri }\end{array}$ & $\begin{array}{l}\text { Piramit Modeli } \\
\text { çerçevesinde } \\
\text { geliştirilmiş sosyal- } \\
\text { duygusal içeriğe } \\
\text { sahip öğretmen } \\
\text { eğitim programı }\end{array}$ & 2 ay & - & - & - & $\begin{array}{l}\text { Sosyal-duygusal } \\
\text { gelişimde } \\
\text { istatistiksel olarak } \\
\text { anlamlı bir iyileşme } \\
\text { ve kaygı düzeyleri } \\
\text { ile saldırgan } \\
\text { davranışlarında } \\
\text { önemli bir azalma }\end{array}$ \\
\hline
\end{tabular}




\section{Bölüm II: Tek Denekli Deneysel Araştırmalar}

Yapılan alanyazın taraması sonucunda Piramit Modelini temel alan müdahale programlarının etkililiğini inceleyen ve $\mathrm{ABD}^{\prime}$ de gerçekleştirilen üç tek denekli deneysel araştırmaya ulaşılmıştır (Artman-Meeker ve Hemmeter, 2013; Fox ve diğerleri, 2011; Hemmeter ve diğerleri, 2015). Bu çalışmalara ilişkin, katılımcı sayıları, araştırma yöntemi, bağımlı ve bağımsız değişkenler, uygulama süresi, uygulama güvenirliği verileri ve bulgular Tablo 2'de sunulurken her bir çalışmanın ayrıntılı bibliyografisi çalışmaların yayınlandığı yıla göre en eskiden en yeniye doğru aşağıda sunulmuştur.

Fox, L., Hemmeter, M. L., Snyder, P., Binder, D. P. \& Clarke, S. (2011). Coaching early childhood special educators to implement a comprehensive model for promoting young children's social competence. Topics in Early Childhood Special Education, 31(3), 178-192.

Araştırmacılar, eğitim, uygulama rehberleri, sınıf materyalleri ve koçluk içeren ve Piramit Modeli stratejilerinin öğretilmesine odaklı çok bileşenli bir mesleki gelişim programının, öğretmenlerin Piramit Modeli stratejilerini uygulama performansları üzerindeki etkilerini tek denekli deneysel araştırma desenlerinden denekler arası çoklu yoklama desenini kullanarak incelemişlerdir. Araştırmanın bağımlı değişkeni, öğretmenlerin Piramit Modeli stratejilerini uygulama düzeyleridir. Araştırmanın bağımsız değişkeni ise yukarıda belirtilen Piramit Modeli stratejilerinin öğretilmesi amacıyla geliştirilmiş̧ çok bileşenli mesleki gelişim programıdır. Araştırma, aynı okul bölgesi içinde bulunan üç farklı ilkokul kampüsünde yer alan, kapsayıcı eğitim uygulaması yapan, üç farklı okul öncesi sınıfında yürütülmüştür. Araştırmaya, bu sınıflarda görev yapan üç kadın okul öncesi öğretmeni katılmıştır. Katılımcıların ikisi lisans, biri yüksek lisans düzeyinde eğitime sahipken tüm katılımcllar erken çocukluk özel eğitim alanında bir dereceye sahiptir. Çalışmaya dahil olan katılımcılar sırasıyla, 37, 35 ve 60 yaşlarındadır ve 16, 12 ve 32 yıl mesleki deneyime sahiptir. Araştırmaya katılan üç sınıfta yaşları 3 ile 5 arasında değişen, 28'i bireyselleştirilmiş eğitim programına sahip toplam 50 çocuk bulunmaktadır.

Çalışmaya katılan her bir öğretmen, Piramit Modeli stratejilerinin ele alındığı üç günlük bir eğitime katıldıktan sonra performans geribildirimi içeren uygulama temelli koçluk desteği almaya başlamıştır. Her koçluk oturumu sırasında 30-90 dakika arasında gözlemler ile 30 dakikalık görüşmeler yapılmıştır. Görüşmeler sırasında öğretmenlere performans temelli geri bildirim sunulmuş, bir sonraki koçluk oturumuna kadar gerçekleştirilmesi planlanan hedefler belirlenmiş ve eylem planı hazırlanmıştır. Koçluk oturumları, bir öğretmenin Piramit Modeli Gözlem Sistemi'nde (Hemmeter, Fox ve Snyder, 2008a) yer alan uygulamaların en az \%80'ini üç oturum art arda doğru uygulayana kadar devam etmiştir. Öğretmenler ölçüte ulaşana dek sırasıyla 11, 8 ve 15 oturum koçluk desteği almışladır. Çalışma kapsamında eğitim ve koçluk oturumlarına ilişkin uygulama güvenirliği verisi sunulmazken, Piramit Modeli Gözlem Sistemi ile yapılan gözlemler için gözlemciler arası güvenirlik verisi rapor edilmiştir. Ortalama gözlemciler arası güvenirlik, üç öğretmen için sirasiyla \%83 (ranj $=\% 66-\% 98), \% 88(\mathrm{ranj}=\% 80-\% 96)$ ve \%81 (ranj $=\% 73-\% 93)$ olarak bulunmuştur. Çalışmanın bulguları, eğitim ve koçluk desteğini içeren mesleki gelişim programının, öğretmenlerin Piramit Modeli stratejilerini doğru bir şekilde kullanmaları üzerinde etkili olduğunu göstermiştir. Dahası, kalıcılık verisi toplanan ilk iki öğretmenin, Piramit Modeli stratejilerini bağımsız bir şekilde uygulamaya devam ettikleri rapor edilmiştir.

Artman-Meeker, K. M. \& Hemmeter, M. L. (2013). Effects of training and feedback on teachers' use of classroom preventive practices. Topics in Early Childhood Special Education, 33(2), 112-123.

Araştırmacılar, Piramit Modeli kapsamında yer alan geçiş hazırlıkları, sınıf kurallarının öğretilmesi ve sosyal-duygusal becerilerin öğretimi ile ilgili stratejileri öğretmeyi amaçlayan ve performans geribildirimi içeren, bir hizmet içi eğitim programının okul öncesi öğretmenlerinin sınıf-içi uygulamaları üzerindeki etkileri ile öğretmen uygulamalarının çocukların sergiledikleri problem davranışlar üzerindeki etkilerini tek denekli deneysel araştırma desenlerinden davranışlar arası çoklu başlama desenini kullanarak incelemişlerdir. Deneysel süreç iki katılımcı grubu ile yinelenmiştir. Araştırmanın bağımlı değişkeni, öğretmenlerin eğitim programı kapsamında sunulan önleyici uygulamaları kullanma düzeyleri ile çocukların sergiledikleri problem davranış düzeyleridir. Araştırmanın bağımsız değişkeni ise, üç farklı Piramit Modeli stratejisini öğretmenlere kazandırmayı hedefleyen, öğretmen eğitim oturumları ile performans geribildiriminden oluşan 
mesleki gelişim programıdır. Araştırma, bir üniversitede yer alan ve kapsayıcı eğitim uygulamaları gerçekleştiren çocuk bakım merkezinde bulunan iki sınıfta yürütülmüştür. Araştırmaya, bu iki sınıfta görev yapan üçü kadın ve biri erkek olmak üzere toplam dört öğretmen, ikişerli ekipler halinde katılmıştır. Katılımcıların üçü lisans derecesine sahipken, biri için eğitim durumu belirtilmemiştir. Katılımcı öğretmenlerin 1 ile 25 yıl arasında $(X=10.5$ yıl) mesleki deneyimleri bulunmaktadır. Öğretmenlere ek olarak, çalışmaya her sınıftan birer çocuk katılmıştır. Çalışmaya katılan 3.5 yaşında kız çocuğu Down Sendromuna sahipken, 4 yaşındaki erkek çocuğu ise dil ve konuşma bozukluğuna sahiptir.

Çalışma kapsamında, öğretmenlere ikişerli gruplar halinde, 1 saat uzunluğunda 3 eğitim oturumu, ortalama 9 gün arayla sunulmuştur. Eğitimlerde sırasıyla geçişler, sınıf kuralları ve sosyal-duygusal becerilerin öğretimi konuları ele alınmıştır. Her eğitimi takiben haftada iki defa öğretmenlerin uygulama yaptığı sınıflarda video kaydı tutulmuş, bu kayıtlar temel alınarak aynı gün içerisinde öğretmenlere e-mail yoluyla performans geribildirimi verilmiştir. E-mail yoluyla sunulan geribildirim Fox ve diğerleri (2011) tarafından geliştirilen beş bileşeni içermiştir: selamlama, öğretmen uygulamaları ile ilgili verilerin sunulması, destekleyici geribildirim, düzenleyici geribildirim ve öğretmenin e-maile cevap vermesini teşvik eden kapanış ifadesi. Çalışma kapsamında hem eğitim programının uygulanması hem de e-posta yoluyla geribildirim sunulmasına ilişkin uygulama güvenirliği verisi ile bağımlı değişkenlerle ilgili veri toplamak için yapılan gözlemler için gözlemciler arası güvenirlik verileri rapor edilmiştir. Bu bağlamda, eğitimler için uygulama güvenirliği \%100 olarak belirlenirken, e-posta yoluyla geribildirim için uygulama güvenirliği ortalama \%98 (ranj $=\% 83$ - \%100) olarak belirlenmiştir. Gözlemciler arası güvenirliğin ise \%82 ile \%99 arasında olduğu rapor edilmiştir. Araştırma bulguları, eğitim ile birlikte e-posta yoluyla sunulan performans geribildiriminin öğretmenlerin Piramit Modeli kapsamında yer alan stratejileri kullanmaları üzerinde etkili olduğunu ortaya koymuştur. Birinci öğretmen ekibinin sınıfında yer alan çocuğun göstermiş olduğu davranış problemlerinde öğretmen uygulamalarındaki gelişmeye paralel olarak bir azalma görülürken, ikinci öğretmen ekibinin sınıfında yer alan çocuğun problem davranış düzeyinde istendik yönde değişim gözlenmemiştir.

Hemmeter, M. L., Hardy, J. K., Schnitz, A. G., Adams, J. M. \& Kinder, K. A. (2015). Effects of training and coaching with performance feedback on teachers' use of Pyramid Model practices. Topics in Early Childhood Special Education, 35(3), 144-156.

Bu çalışmada araştırmacılar, eğitim (çalıştay), koçluk ve performans geribildirimi içeren bir mesleki gelişim programının okul öncesi öğretmenlerinin sınıflarında Piramit Modeli stratejilerini uygulama düzeyleri üzerindeki etkilerini tek denekli deneysel araştırma desenlerinden davranışlar arası çoklu yoklama desenini kullanarak incelemişlerdir. Deneysel süreç üç katılımcı ile yinelenmiştir. Araştırmanın bağımlı değişkeni, öğretmenlerin sınıflarında Piramit Modeli stratejilerini uygulama düzeyleridir. Araştırmanın bağımsız değişkeni ise Piramit Modeli temelli, eğitim, koçluk ve performans geribildirimi içeren mesleki gelişim programıdır. Araştırma, aynı okul bölgesinde üç farklı ilkokul bünyesinde kapsayıcı eğitim uygulamaları yapılan üç okul öncesi eğitimi sınıfında yürütülmüştür. Çalışmaya bu sınıflarda görev yapan üç kadın okul öncesi öğretmeni katılmıştır. Öğretmenlerden biri lisans, ikisi yüksek lisans düzeyinde eğitim almışlardır ve öğretmenlerin 2-8 yıl $(X=5.3$ yıl $)$ arasında mesleki deneyimleri bulunmaktadır. Çalışmaya katılan öğretmenlerin sınıflarında 2-4 tanesi devam eden problem davranışlara sahip çocuklar olmak üzere toplam 14-16 arası çocuk yer almaktadır. 
Okul Öncesi Dönemde Sosyal-Duygusal Gelişimin Desteklenmesi...

Tablo 2. Piramit Modelinin Etkililiğini İnceleyen Tek Denekli Deneysel Araştırmaların Özeti

\begin{tabular}{|c|c|c|c|c|c|c|c|c|c|c|}
\hline \multirow{2}{*}{ Kaynak } & \multicolumn{2}{|c|}{ Katılımcılar } & \multirow{2}{*}{ Araştırma Yöntemi } & \multirow{2}{*}{ Bağımlı Değişken } & \multirow{2}{*}{$\begin{array}{l}\text { Bağımsız } \\
\text { Değişken }\end{array}$} & \multirow{2}{*}{$\begin{array}{l}\text { Uygulama } \\
\text { Süresi }\end{array}$} & \multicolumn{2}{|c|}{ Uygulama Güvenirliği } & \multicolumn{2}{|c|}{ Bulgular } \\
\hline & Öğretmen & Çocuk & & & & & Çalıştay & Koçluk & Öğretmen & Çocuk \\
\hline 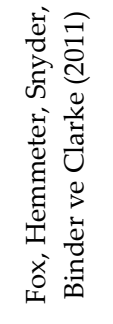 & 3 & - & $\begin{array}{l}\text { Denekler arası çoklu } \\
\text { yoklama deseni }\end{array}$ & $\begin{array}{l}\text { Öğretmenlerin Piramit } \\
\text { Modeli stratejilerini } \\
\text { uygulama düzeyleri }\end{array}$ & $\begin{array}{l}\text { Çok bileşenli } \\
\text { mesleki gelişim } \\
\text { programı }\end{array}$ & $\begin{array}{l}3 \text { gün süreyle } \\
\text { eğitim } \\
\text { 8-15 koçluk } \\
\text { oturumu }\end{array}$ & - & - & $3 / 3$ & - \\
\hline 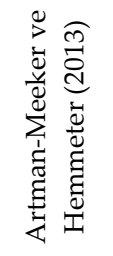 & 4 & 2 & $\begin{array}{l}\text { Davranışlar arası } \\
\text { çoklu başlama } \\
\text { deseni }\end{array}$ & $\begin{array}{l}\text { Öğretmenlerin Piramit } \\
\text { Modeli stratejilerini } \\
\text { uygulama düzeyleri } \\
\text { ve çocukların problem } \\
\text { davranış düzeyleri }\end{array}$ & $\begin{array}{l}\text { Öğretmen eğitimi } \\
\text { ve performans } \\
\text { geribildiriminden } \\
\text { oluşan mesleki } \\
\text { gelişim programı }\end{array}$ & $\begin{array}{l}3 \text { saat eğitim } \\
\text { ve performans } \\
\text { bildirimi }\end{array}$ & $\% 100$ & $\begin{array}{c}\% 98 \\
\text { (e-posta ile } \\
\text { geri } \\
\text { bildirim) }\end{array}$ & $4 / 4$ & $1 / 2$ \\
\hline 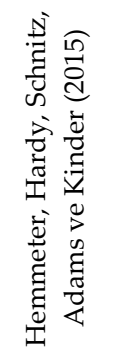 & 3 & $14-16$ & $\begin{array}{l}\text { Davranıslar arası } \\
\text { çoklu yoklama } \\
\text { deseni }\end{array}$ & $\begin{array}{l}\text { Öğretmenlerin Piramit } \\
\text { Modeli stratejilerini } \\
\text { uygulama düzeyleri } \\
\text { ve çocukların problem } \\
\text { davranış düzeyleri }\end{array}$ & $\begin{array}{l}\text { Eğitim, koçluk ve } \\
\text { performans } \\
\text { geribildirimi } \\
\text { içeren mesleki } \\
\text { gelişim programı }\end{array}$ & $\begin{array}{l}3 \text { saat eğitim } \\
\text { ve takip eden } \\
\text { koçluk } \\
\text { oturumları }\end{array}$ & - & $\% 99$ & $3 / 3$ & - \\
\hline
\end{tabular}

Not. Bulgular başlığı altında sunulan veriler çalışma sonunda ölçüt düzeyi performans ya da gelişim gösterdiği rapor edilen katılımcı sayılarını belirtmektedir. 
Çalışma kapsamında her bir öğretmene Piramit Modeli kapsamında yer alan üç grup strateji öğretilmiştir. Her bir strateji grubu için öğretmen 1 saatlik bir eğitime katılmış ve daha sonra performans geribildirimi içeren uygulama temelli koçluk yardımı almaya başlamıştır. Her öğretmen, bir strateji grubunda yer alan stratejileri, üç ardışık veri toplama oturumunda en az \%80 düzeyinde doğruluk ile uyguladığında, o strateji seti için koçluk desteği sonlandırılmış ve öğretmen yeni strateji seti için eğitime tabi tutulmuştur. Çalışma, bu şekilde her öğretmen üç strateji setinde de ölçüte ulaşana kadar devam etmiştir. Çalışma kapsamında öğretmenlerin, Piramit Modeli stratejilerini uygulama düzeyleri Piramit Modeli Gözlem Sistemi (Hemmeter ve diğerleri, 2008a) ile veri toplanması yoluyla belirlenirken, çalışmaya katılan öğretmenlerin sınıflarında yer alan çocukların problem davranış düzeyleri Sınıf-Temelli Problem Davranış Gözlem Sistemi (Hemmeter, Fox ve Snyder, 2008b) kullanılarak belirlenmiştir. Çalışmada koçluk oturumlarının en az \%40'ında uygulama güvenirliği verisi toplanmış ve uygulama güvenirliğinin ortalama \%99 (ranj = \%91 - \%100) olduğu rapor edilmiştir. Veri toplama amacıyla yapılan gözlemlerin en az \%40'ında gözlemciler arası güvenirlik verisi toplanmıştır. Piramit Modeli Gözlem Sistemi için gözlemciler arası güvenirlik katsayısı, ortalama \%88 (ranj = \%84 - \%90) olarak rapor edilirken, Sınıf-Temelli Problem Davranış Gözlem Sistemi için ise \%99 (ranj = \%98 \%100) olarak belirlenmiştir. Çalışmanın bulguları, uygulanan mesleki gelişim programının öğretmenlerin Piramit Modeli stratejilerini öğrenmeleri ve uygulamaları üzerinde etkili olduğunu, üç katılımcının da öğrendikleri uygulamaları sürdürdüklerini ve bazı etkinliklere genellediklerini göstermiştir. Ek olarak, üç öğretmenden ikisinin sınıfında yer alan çocukların problem davranışlarında önemli düzeyde azalma olduğu görülmüştür.

\section{Bölüm III: Betimsel Araştırmalar}

Yapılan alanyazın taraması sonucunda, okul öncesi öğretmenlerinin hiçbir eğitim almadan Piramit Modeli kapsamında yer alan stratejileri kullanma düzeylerini belirlemek amacıyla Güney Kore, Çin, ABD ve Türkiye'de yürütülen dört betimsel çalışmaya ulaşılmıştır (Heo ve diğerleri, 2014; Luo ve diğerleri, 2017; Rakap, Balikci ve diğerleri, 2018; Steed ve Roach, 2017). Bu çalışmalara ilişkin, amaç, katılımcı sayıları, veri toplama araçları ve temel bulgular Tablo 3'te sunulurken ve her bir çalışmanın ayrıntılı bibliyografisi çalışmaların yayınlandığı yıla göre en eskiden en yeniye doğru aşağıda sunulmuştur.

Heo, K. H., Cheatham, G. A., Hemmeter, M. L. \& Noh, J. (2014). Korean early childhood educators' perceptions of importance and implementation of strategies to address young children's social-emotional competence. Journal of Early Intervention, 36(1), 49-66.

Bu çalışmada araştırmacılar, Güney Kore' de görev yapan, 256 erken çocukluk dönemi eğitimcisinin küçük çocukların sosyal-duygusal gelişimlerini destekleme konusundaki görüş ve uygulamaları ile bu görüş ve uygulamaların çeşitli değişkenlere (stratejilerin önemi hakkındaki tutum, özel eğitim deneyimi, erken çocukluk eğitiminde mesleki deneyim, çocukların sınıf ve yaş düzeyi) göre farklılaşıp farklılaşmadığını incelemişlerdir. Çalışmaya katılan öğretmenlerin 194'ü (\%76) en az dört yıllık üniversite eğitimine sahipken, 110'unun (\%43) sınıfında özel gereksinimli çocuk bulunmaktadır. Öğretmenlerin erken çocukluk eğitimi ve özel eğitim konusundaki mesleki deneyimleri çeşitlilik göstermektedir: 117 (\%46) öğretmenin erken çocukluk ortamlarındaki öğretim deneyimi 3-5 yıl arasındayken 119 (\%47) öğretmenin özel gereksinimli çocuklar ile çalışma deneyimi üç yılın altındadır.

Çalışmada veri toplama işlemleri Piramit Modeli Gözlem Sistemi (PMGS; Hemmeter ve diğerleri, 2008a) kullanılarak gerçekleştirilmiştir. Bu bağlamda, gözlem sistemindeki maddelerin iki ölçeğe dönüştürülerek öğretmenler tarafından tamamlanması sağlanmıştır. Birinci ölçekte öğretmenlerden, gözlem sisteminde yer alan her bir stratejiyi önemli bulup bulmadıklarını 4 puanlı bir derecelendirme sistemi (1=Hiç önemli değil, 2=Önemli değil, 3=Önemli, 4=Çok önemli) kullanarak belirtmeleri istenmiştir. İkinci ölçekte ise öğretmenlerden, gözlem sisteminde yer alan her bir stratejiyi ne sıklıkla uyguladıklarını 4 puanlı bir derecelendirme sistemi (1=Hiç, 2=Bazen, 3=Sık, 4=Çok Sık) kullanarak belirtmeleri istenmiştir. Çalışmanın bulguları, katılımcı öğretmenlerin birçoğunun küçük çocuklarda sosyal-duygusal gelişimin desteklenmesine yönelik stratejilerin kullanılmasının önemine inandıklarını, ancak sosyal-duygusal gelişimi desteklemeye yönelik stratejileri düşük düzeylerde uyguladıklarını ortaya koymuştur. Ek olarak, öğretmenlerin sosyal- 
duygusal gelişimi desteklemeye yönelik strateji kullanımını en iyi kestiren değişkenin, öğretmenlerin bu stratejilerin önemi hakkındaki tutumları olduğu bulunmuştur.

Luo, L., Snyder, P., Clark, C. L. \& Hong, X. (2017). Preschool teachers' use of pyramid model practices in Mainland China. Infants ve Young Children, 30(3), 221-237.

Bu çalışmada araştırmacılar, Çin'de görev yapmakta olan okul öncesi öğretmenlerinin Piramit Modeli kapsamında yer alan stratejileri uygulama düzeylerini incelemişlerdir. Bu çalışmaya anasınıflarında tam zamanlı olarak çalışan 20 kadın öğretmen dâhil olmuştur. Çalışmaya katılan öğretmenlerin tamamı erken çocukluk eğitimi alanında ulusal bir sertifikaya sahip olduğunu rapor ederken, 10 öğretmen erken çocukluk eğitimi alanında lisans diplomasına, 4 öğretmen erken çocukluk eğitimi alanında ön lisans derecesine, 1 öğretmen erken çocukluk eğitimi alanında yüksek lisans derecesine ve 5 öğretmen de başka alanlarda lisans derecesine (örn., sanat eğitimi, erken çocukluk özel eğitimi, çocuk edebiyatı) sahip olduğunu belirtmiştir. Çalışmaya katılan öğretmenlerin ortalama mesleki kıdem süresi 10,4 yıl (ranj = 1-30 yıl) ve görev yaptıkları okuldaki çalışma süreleri ise 7,5 yıldır (ranj = 1-22 yıl). Öğretmenlerden altısı çocuklarda sosyal-duygusal gelişim ile ilgili dördü ise problem davranışlar ile baş etme konusunda eğitim aldıklarını rapor etmiştir. Çalışmaya dâhil olan 20 öğretmenin sınıfında kayıtlı 8'i görme ya da işitme yetersizliğine sahip toplamda 656 çocuk bulunmaktadır. Öğretmenlerin 13'ü (\%65), sınıflarında sürekli problem davranışlar sergileyen çocukların olduğunu bildirmiştir.

Çalışmada veriler PMGS (Hemmeter ve diğerleri, 2008a) kullanılarak toplanmıştır. Araştırmanın sonunda, çalışmaya katılan okul öncesi öğretmenlerinin, Piramit Modeli ile ilgili stratejilerin ortalama \%30.89'unu kullandıkları ortaya çıkmıştır. Araştırmada, okul öncesi öğretmenlerinin hedeflenen sosyalduygusal öğretim uygulamalarından ziyade evrensel düzeydeki öğretim uygulamalarını kullandıkları, davranış beklentileri ve sosyal problem çözme becerileri ile ilgili olarak öğretim uygulamalarına yer vermedikleri ve problem davranışları fazla olan çocuklar için bireysel müdahaleler geliştirmedikleri gözlemlenmiştir.

Steed, E. A. \& Roach, A. T. (2017). Childcare providers' use of practices to promote young children's socialemotional competence. Infants and Young Children, 30(2), 162-171.

Bu çalışmada, ABD'de okul öncesi sınıflarında görev yapan ve daha önce küçük çocukların sosyalduygusal gelişimini desteklemeye ya da Piramit Modeli'ne odaklı bir mesleki gelişim programına katılmamış öğretmenlerin Piramit Modeli uygulamalarını kullanma düzeyleri incelenmiştir. Çalışmaya 3-5 yaş grubundaki çocuklara hizmet veren 38 okul öncesi eğitim sınıfında görev yapan, tümü kadın olan ve ortalama 6.73 yıllık mesleki deneyime sahip 38 öğretmen katılmıştır. Öğretmenlerden çoğunun lisans derecesine sahip olduğu \%39'unun ise ön lisans derecesi aldığı belirtilmiştir. Çalışmaya, 38 sınıfta öğrenim gören, yaş ortalaması 4.10 olan, 389 'u kız (\%51) toplam 763 çocuk katılmıştır. Çocukların \%12'sinin İngilizceyi ikinci bir dil olarak öğrendiği ve \%1'inin ise bir özel gereksinime sahip olduğu rapor edilmiştir.

Çalışmada veriler, PMGS (Hemmeter ve diğerleri, 2008a) ile Okul Öncesi Değerlendirme Aracı (PreSET; Steed, Pomerleau ve Horner, 2012) kullanılarak toplanmıştır. Bu çalışmanın bulguları, öğretmenlerin hiçbir eğitim almadan, Piramit Modeli kapsamında yer alan sosyal-duygusal gelişimi destekleyici stratejilerin çok azını kullandıklarını göstermiştir. Ayrıca, öğretmenlerin, çocukların arkadaşlık kurma, problem çözme ve kendini ifade etme becerilerini geliştirmeyi amaçlayan öğretim uygulamalarını nadiren kullandıklarını ve çocukların sergilediği problem davranışları önlemeye ve bunlarla başa çımaya yönelik sistematik bir yaklaşım kullanmadıkları belirlenmiştir. Bu çalışmanın sonuçları, okul öncesi eğitim ortamlarında küçük çocukların sosyal-duygusal gelişimlerini desteklemeye ve problem davranışlarını önlemeye yönelik stratejilerin uygulanmasını desteklemek için uygulama desteği içeren mesleki gelişim programlarının önemini vurgulamaktadır. 
Sinan KALKAN \& Salih RAKAP

Tablo 3. Okul Öncesi Öğretmenlerinin Piramit Modeli Stratejilerini Kullanma Düzeylerini İnceleyen Betimsel Araştırmalar

\begin{tabular}{|c|c|c|c|c|}
\hline Kaynak & Amaç & Katılımclar & $\begin{array}{c}\text { Veri Toplama } \\
\text { Araçları }\end{array}$ & Bulgular \\
\hline 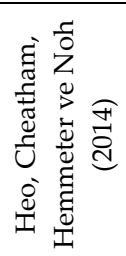 & $\begin{array}{l}\text { Güney Kore'de görev yapan öğretmenlerin küçük } \\
\text { çocukların sosyal-duygusal gelişimlerini destekleme } \\
\text { konusundaki görüş ve uygulamaları ile bu görüş ve } \\
\text { uygulamaların çeşitli değişkenlere göre farklılaşıp } \\
\text { farklılaşmadığının incelenmesi }\end{array}$ & 256 & PMGS & $\begin{array}{l}\text { Katılımcı öğretmenlerin birçoğunun küçük çocuklarda sosyal-duygusal } \\
\text { gelişimin desteklenmesine yönelik stratejilerin kullanılmasının önemine } \\
\text { inandıkları (M=3.09-3.44), ancak sosyal-duygusal gelişimi desteklemeye } \\
\text { yönelik stratejileri düşük düzeylerde uyguladıkları }(\mathrm{M}=2.34-2.86) \\
\text { bulunmuştur. }\end{array}$ \\
\hline 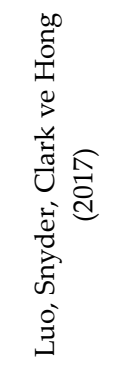 & $\begin{array}{l}\text { Çin'de görev yapan okul öncesi öğretmenlerinin } \\
\text { Piramit Modeli kapsamında yer alan stratejileri } \\
\text { uygulama düzeylerinin incelenmesi }\end{array}$ & 20 & PMGS & $\begin{array}{l}\text { Okul öncesi öğretmenlerinin, Piramit Modeli kapsamında yer alan } \\
\text { stratejilerin ortalama \%31'ini (ranj=\%7-\%61) kullandıkları, hedeflenen } \\
\text { sosyal-duygusal öğretim uygulamalarından ziyade evrensel düzeydeki } \\
\text { öğretim uygulamalarını kullandıkları belirlenmiştir. }\end{array}$ \\
\hline 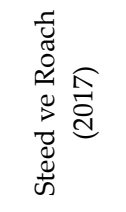 & $\begin{array}{l}\text { ABD'de görev yapan okul öncesi öğretmenlerinin } \\
\text { Piramit Modeli stratejilerini kullanma düzeylerinin } \\
\text { incelenmesi }\end{array}$ & 38 & $\begin{array}{l}\text { PMGS } \\
\text { OÖDA }\end{array}$ & $\begin{array}{l}\text { Öğretmenlerin Piramit Modeli kapsamında yer alan sosyal-duygusal } \\
\text { gelişimi desteklemeye ve problem davranışları önlemeye yönelik } \\
\text { stratejileri sınırlı düzeyde (M=\%47; ranj =\%0-\%88) kullandıkları } \\
\text { belirlenmiştir. }\end{array}$ \\
\hline 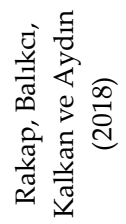 & $\begin{array}{l}\text { Türkiye'de görev yapan okul öncesi öğretmenlerinin } \\
\text { Piramit Modeli kapsamında yer alan stratejileri } \\
\text { uygulama düzeylerinin incelenmesi }\end{array}$ & 103 & PMGS & $\begin{array}{l}\text { Okul öncesi öğretmenlerinin, eğitim ve mesleki gelişim desteği olmadan, } \\
\text { küçük çocuklarda sosyal-duygusal yeterliliği teşvik etmek ve problem } \\
\text { davranışları önlemek için Piramit Modeli kapsamında yer alan } \\
\text { stratejileri çok sınırlı düzeyde (M=\%14; ranj = \%7-\%40) kullandıkları } \\
\text { bulunmuştur. }\end{array}$ \\
\hline
\end{tabular}

Not. PMGS= Piramit Modeli Gözlem Sistemi; OÖDA= Okul Öncesi Değerlendirme Aracı. 
Rakap, S., Balikci, S., Kalkan, S. \& Aydin, B. (2018). Preschool Teachers' Use of Strategies to Support SocialEmotional Competence in Young Children. International Journal of Early Childhood Special Education, 10(1), 1125.

Bu çalışma, Türkiye'de okul öncesi kurumlarında görev yapan öğretmenlerinin sınıflarındaki çocukların sosyal-duygusal gelişimini desteklemek ve problem davranışlarını önlemek için kullandıkları stratejileri belirlemek üzere gerçekleştirilmiştir. Çalışmaya, 3-5 yaş grubundaki çocuklara hizmet veren 103 okul öncesi sınıfında görev yapan 101'i kadın, 2'si erkek toplam 103 öğretmen katılmıştır. Çalışmaya katılan öğretmenlerin tümü okul öncesi öğretmenliği alanında lisans derecesine sahip olup, 6's1 (\%6) okul öncesi öğretmenliği veya ilişkili alanlarda yüksek lisans derecesine sahiptir. Bu çalışmada öğretmenlerin, ortalama 11.31 yıllık mesleki deneyime ( $\mathrm{SD}=5.94)$ sahip olduğu rapor edilmiştir. Çalışmaya katılan öğretmenlerden, $45^{\prime} \mathrm{i}(\% 44)$ sosyalduygusal gelişim, 65'i (\%63) problem davranışlar ve 29'u ise (\%28) hem sosyal-duygusal gelişim hem de problem davranış konularına odaklanmış eğitimlere katıldığını belirtmiştir. Araştırmaya dâhil olan okul öncesi öğretmenleri, daha önce Piramit Modeli'ne odaklanan herhangi bir mesleki gelişim programına katılmadıklarını rapor etmişlerdir.

Çalışmaya katılan öğretmenlerin, 33'ü (\%32) genel okul öncesi eğitim sınıflarında, 35'i (\%34) kaynaştırma eğitimi uygulayan okul öncesi sınıflarında ve 35'i (\%34) ayrıştırılmış okul öncesi sınıflarında görev yaparken; çalışma kapsamında yer alan 103 sınıftan, 31'inde (\%30) 3 yaş grubundaki çocuklara, 33'ünde (\%32) 4 yaş grubundaki çocuklara ve 39'unda (\%38) 5 yaş grubundaki çocuklara eğitim verilmekteydi. Çalışma sırasında sınıflarda 5 ile 21 arasında çocuk $(M=11.77, S D=4.10)$ eğitim alırken 1 ile 3 yetişkin $(M=2.18, S D=.69)$ görev yapmıştır. Çalışma kapsamında veriler PMGS (Fox ve diğerleri, 2014) kullanılarak toplanmıştır. Araştırmanın bulguları, okul öncesi öğretmenlerinin, eğitim ve mesleki gelişim desteği olmadan, küçük çocuklarda sosyalduygusal yeterliliği teşvik etmek ve problem davranışları önlemek için Piramit Modeli kapsamında yer alan stratejileri çok sınırlı düzeyde (ortalama \%14) kullandıklarını göstermiştir. Ayrıca, bulgular, çalışmaya katılan öğretmenlerin uygulama düzeylerinin sınıf türü ve düzeyine göre farklılık göstermediğini ortaya koymuştur.

\section{Tartışma ve Sonuç}

$\mathrm{Bu}$ ayrıntılı bibliyografi çalışmasında, okul öncesi dönemde Piramit Modelini temel alan grup ve tekdenekli deneysel ve betimsel araştırmalar incelenmiştir. Grup desenli çalışmalardan ikisinde (Fettig ve Artman-Meeker, 2016; Hemmeter ve diğerleri, 2016), Piramit Modeli kapsamında yer alan stratejilerin öğretmenlere kazandırılması bağlamında öğretmen eğitimi çalıştaylarına ilaveten uygulama desteğine yer verilmiş ve mesleki gelişim programının öğretmenlerin uygulama performansları ile çocuk çıktıları üzerindeki etkileri incelenmiştir. Lam ve Wong (2017) tarafından yürütülen üçüncü çalışmada ise eğitim çalıştaylarına yer verilmiş ve öğretmenlerin Piramit Modeli stratejilerini kullanma düzeyleri ile çocuk çıktıları üzerindeki etkileri incelenmiştir. Bu çalışmaların bulguları, öğretmen eğitimi çalıştaylarını ve uygulama desteği içeren mesleki gelişim programlarının öğretmenlerin uygulama performansları ile çocuk çıtıları üzerindeki etkilerini açık bir şekilde ortaya koymaktadır. Benzer şekilde tek denekli deneysel çalı̧̧malarda da (ArtmanMeeker ve Hemmeter, 2013; Fox ve diğerleri, 2011; Hemmeter ve diğerleri, 2015) bireysel ya da küçük grup halinde sunulan mesleki gelişim programlarının (öğretmen eğitimi çalıştayları ve ardından sunulan uygulama temelli koçluk desteği), öğretmenlerin Piramit Modeli stratejilerini kullanma düzeyleri ile çocuk çıtıları üzerindeki etkileri incelenmiş olup, bu çalışmaların sonuçları da grup desenli deneysel araştırmalarda olduğu gibi uygulanan mesleki gelişim programlarının öğretmen ve çocuk çıtıları etkililiğini ortaya koymaktadır.

Bu çalışma kapsamında incelenen araştırmalar, okul öncesi öğretmenlerinin Piramit Modeli gibi çok bileşenli ve kapsamlı çerçeve programlarını çocuk çıktıları üzerinde olumlu sonuçlar doğuracak şekilde doğru ve sık olarak kullanabilmek için yüksek nitelikli ve birden fazla oturumdan oluşan öğretmen eğitimleri ve eğitimleri takiben sunulan uygulama desteği içeren mesleki gelişim programlarına gereksinim duyduklarını göstermektedir. Bu bağlamda, son dönemde yürütülen birçok araştırma (Powell ve Diamond, 2013; Rakap, 2017; Rakap, Balikci ve diğerleri, 2018; Rakap, Kalkan, Balikci ve Aydin, 2018; Snyder, Hemmeter, McLean, Sandall, McLaughlin ve Algina, 2018), öğretmenlerin uygulama performanslarını desteklemek amacıyla geliştirilen mesleki gelişim programlarının, eğitimleri takiben uygulama desteği içermesi (örn., uygulama temelli koçluk) ve öğretmenlere sunulan uygulama desteğinin uzun süreli planlanması gerektiğini 
vurgulamaktadır. Bu bağlamda, uygulama temelli koçluk desteği planlama, gözlem ve geribildirim bileşenlerinden oluşan döngüsel bir yapı içerisinde sunulurken her aşamada öğretmenin aktif katılımını gerektirmektedir (Rakap ve Kalkan, 2018). Bu döngüsel süreç, öğretmenlerin eğitim oturumları sırasında öğrendikleri stratejileri sınıf ortamına aktarmaları bağlamında planlama yapma ve uygulama sürecinde uzman bir kişiden (bir koçtan) destek ve geribildirim almalarına olanak tanırken öğretmenlerin süreç içerisinde değişen ihtiyaçları göz önüne alınarak gerekli düzenlemelerin yapılmasına da olanak tanır (Rakap, Balıkcı ve Vural-Batık, 2015).

Öğretmenlerin Piramit Modeli stratejilerini kullanma düzeylerini belirlemek amaciyla Güney Kore (Heo ve diğerleri, 2014), Çin (Luo ve diğerleri, 2017), ABD (Steed ve Roach, 2017) ve Türkiye'de (Rakap, Balikci ve diğerleri, 2018) yürütülen betimsel çalışmalar ise ülkeler arasında bazı farklılıklar olmasına rağmen bir mesleki gelişim desteği olmaksızın öğretmenlerin Piramit Modeli stratejilerini yaygın bir şekilde kullanamadıklarını göstermektedir. Ülkeler arasındaki uygulama farklarına bakıldığında ABD'de görev yapan okul öncesi öğretmenlerinin Piramit Modeli kapsamında yer alan stratejilerin yaklaşık olarak yarısını düzenli bir şekilde kullandıkları, Çin'de bu oranın üçte bir, Türkiye'de ise altıda bir olduğu görülmektedir. Güney Kore'de görev yapan öğretmenler ise Piramit Modeli stratejilerinin birçoğunu bazen ya da sık olarak kullandıklarını rapor etmişlerdir. Öğretmenlerin uygulama performanslarındaki bu farklılıkların hizmet öncesi ve hizmetiçi dönemde küçük çocukların sosyal-duygusal gelişimini desteklemeye ve problem davranışlarını önlemeye yönelik aldıkları, doğrudan Piramit Modeli stratejilerine odaklanmayan eğitimlerden kaynaklanabileceği düşünülmektedir. Türkiye'de okul öncesi öğretmenliği lisans programı incelendiğinde, doğrudan küçük çocukların sosyal-duygusal gelişimlerini desteklemeye yönelik bir dersin bulunmadı̆̆ı görülmektedir (Yükseköğretim Kurulu Başkanlığı, 2018). Dahası, Milli Eğitim Bakanlığı (MEB), Öğretmen Yetiştirme ve Geliştirme Genel Müdürlüğü tarafından 2001-2018 yılları arasında geliştirilen hizmetiçi eğitim planları incelendiğinde, bu tarihler arasında okul öncesi öğretmenlerinin mesleki gelişimlerini desteklemek amaciyla birçok seminer ve kurs planlaması yapıldığı, ancak bu hizmetiçi eğitim faaliyetlerinin nadiren küçük çocukların sosyal-duygusal gelişimlerini desteklemeye ve problem davranışlarını önlemeye yönelik yaklaşımlara ve bilimsel dayanaklı uygulamalara odaklandığı görülmektedir (Kalkan, 2019). Okul öncesi öğretmen yetiştirme programında, küçük çocukların diğer alanlarındaki gelişimleri için son derece önemli bir role sahip olan sosyal-duygusal gelişimin desteklenmesine yönelik belirli bir dersin olmamasının ve hizmetiçi dönemde gerçekleştirilen mesleki gelişim faaliyetlerinin bu konuya nadiren odaklanmış olmasının, okul öncesi öğretmenlerinin sosyal-duygusal gelişimi desteklemeye ve problem davranışları önlemeye yönelik stratejileri çok sınırlı düzeyde kullanmalarına yol açtı̆̆ı düşünülmektedir.

Dünyanın birçok ülkesinde ve Türkiye'de öğretmenlerin mesleki gelişimlerini sürdürmeleri genellikle, hizmet öncesi eğitimi takiben periyodik aralıklarla sunulan hizmetiçi eğitimlerle desteklenmektedir. Araştırmalar, öğretmenlerin mesleki gelişimlerini desteklemek amacıyla, gereksinimleri dikkate alınmadan, genellikle bir ya da iki oturumdan oluşan ve beceri kazandırmadan daha çok bilgi aktarımına odaklanan mesleki gelişim faaliyetlerinin, öğretmenlerin uygulama performanslarını iyileştirmede ve geliştirmede oldukça sınırlı bir etkiye sahip olduğunu ortaya koymaktadır (Snyder ve Wolfe, 2008). Ulusal ve uluslararası alanyazında farklı mesleki gelişim modellerinin etkililiğini karşılaştırmalı olarak inceleyen araştırmaların sonuçları, birden fazla oturumdan oluşan yüksek kaliteli öğretmen eğitim çalıştayları ile performans geribildirimi içeren uygulama desteğinden oluşan mesleki gelişim programlarının, öğretmenlerin uygulama performanslarını desteklemede, bu bileşenleri içermeyen diğer programlara oranla daha etkili olduğunu göstermektedir (Hemmeter ve diğerleri, 2016; Rakap, 2017; Rakap, Balikci ve diğerleri, 2018; Rakap, Kalkan ve diğerleri, 2018; Snyder ve diğerleri, 2018).

Sonuç olarak bu çalışma kapsamında incelenen araştırmaların sonuçları, öğretmenler için geliştirilen ve bilimsel dayanaklı olduğu kanıtlanmış yöntemlerin öğretilmesini amaçlayan mesleki gelişim programlarının etkili olabilmesinin, bu programların planlanmasında ve sunulmasında etkili yaklaşımların tercih edilmesiyle doğrudan ilişkili olduğunu göstermektedir. Öğretmenlerin mesleki bilgi ve becerilerini desteklemek amaciyla geliştirilen mesleki gelişim programlarının içeriği ne denli kapsamlı ve bilimsel dayanaklı olursa olsun, bu programlar öğretmenlere etkili yöntem ve stratejiler kullanılarak sunulmadıkça ve öğretmenlere eğitimler 
sırasında öğrendiklerini sınıflarına aktarmaları için uygulama desteği sağlanmadıkça, öğretmenlerin öğretime ilişkin uygulama performanslarının iyileştirilmesi ve öğretmen uygulamalarının çocuk çıtılarını olumlu yönde etkilemesi oldukça güç görünmektedir (Arıkan, Fernie ve Kantor, 2017; Fox ve diğerleri, 2011; Linder, Rembert, Simpson ve Ramey, 2016; Rakap, 2017; Snyder, Hemmeter, Artman, Kinder, Pasia ve McLaughlin, 2012). Bu nedenle, öğretmenlere sunulan mesleki gelişim programları, öğretmenlerin uygulama performanslarını destekleyici nitelikte olmalıdır (Rakap, 2017). Ayrıca çocukların gelişiminde önemli bir yeri olan sosyal-duygusal gelişimin lisans düzeyinde daha ayrıntılı olarak ele alınması ve bu bağlamda öğretmen adaylarına önleyici ve iyileştirici nitelikteki müdahale programlarının uygulanmasına yönelik becerilerin kazandırılması önerilmektedir. Bu çalışmanın bulguları, ulusal ve uluslararası alanyazında Piramit Modeli'nin etkililiğini inceleyen daha çok araştırmaya gereksinim olduğunu göstermekle birlikte okul öncesi öğretmenlerine Piramit Modeli stratejilerini kazandırmada etkili olan mesleki gelişim yaklaşımlarının belirlenmesine yönelik çalışmalara olan ihtiyacı işaret etmektedir. Dahası, Piramit modeli temelinde geliştirilen müdahale programlarının etkililiğinin karşılaştırılmalı olarak incelenmesine yönelik araştırmalara da gereksinim duyulmaktadır.

\section{Yazar(lar)ın Beyanı}

Araştırmacıların katkı oranı beyanı: Araştırmacılar çalışmaya eşit oranda katkı yapmışlardır.

Etik Kurul Kararı: Bu araştırma bir derleme çalışması olduğu için etik kurul iznine gerek duyulmamaktadır.

Çatışma beyanı: Araştırmada yazarlar arasında ya da diğer kişi/kurum/kuruluşlarla herhangi bir çıar çatışması bulunmamaktadır.

Destek ve teşekkür: Bu araştırma için herhangi bir kurumdan finansal destek alınmamıştır.

\section{Kaynaklar}

Arıkan, A., Fernie, D. E., \& Kantor, R. (2017). Supporting the professional development of early childhood teachers in head start: A case of acquiring technology proficiency. Ilköğretim Online, 16(4), 1829-1849. https://doi.org/10.17051/ilkonline.2017.342996

Artman-Meeker, K. M. \& Hemmeter, M. L. (2013). Effects of training and feedback on teachers' use of classroom preventive practices. Topics in Early Childhood Special Education, 33(2), 112-123. https://doi.org/10.1177/0271121412447115

Artman-Meeker, K. M. (2010). Effects of distance coaching on teachers' use of a tiered model of intervention and relationships with child behavior and social skills (Doctoral Dissertation). Vanderbilt University, Nashville, Tennessee.

Bambara, L. M. \& Kern, L. (Ed.), (2005). Individualized supports for students with problem behaviors: Designing positive behavior plans. New York, NY: Guilford.

Cristóvão, A. M., Candeias, A. A., \& Verdasca, J. (2017). Social and emotional learning and academic achievement in portuguese schools: A bibliometric study. Frontiers in Psychology, 8, 1-12. https://doi.org/10.3389/fpsyg.2017.01913

Duncan, G. J., \& Magnuson, K. (2011). The nature and impact of early achievement skills, attention skills, and behavior problems. G. J. Duncan \& R. Murnane (Eds.), Whither opportunity? Rising inequality, schools, and children's life chances (s. 47-69) içinde. New York, NY: Russell Sage Foundation.

Durlak, J. A. \& DuPre, E. P. (2008). Implementation matters: A review of research on the influence of implementation on program outcomes and the factors affecting implementation. American Journal of Community Psychology, 41(3-4), 327. https://doi.org/10.1007/s10464-008-9165-0 
Fettig, A. \& Artman-Meeker, K. (2016). Group coaching on pre-school teachers' implementation of pyramid model strategies: A program description. Topics in Early Childhood Special Education, 36(3), 147-158. https://doi.org/10.1177/0271121416650049

Fox, L \& Hemmeter, M. L. (2009). A program-wide model for supporting social emotional development and addressing challenging behavior in early childhood settings. W. Sailor, G. Dunlap, G. Sugai ve R. Horner (Eds.), Handbook of positive behavior support (s. 177-202) içinde. New York, NY: Springer.

Fox, L., Dunlap, G., Hemmeter, M. L., Joseph, G. E., \& Strain, P. S. (2003). The teaching pyramid: A model for supporting social competence and preventing challenging behavior in young children. Young Children, $58(4), 48-52$.

Fox, L., Hemmeter, M. L., \& Snyder, P. S. (2014). Teaching Pyramid Observation Tool for preschool classrooms $\left(\right.$ TPOT $\left.^{\mathrm{TM}}\right)$. Research Edition. Baltimore, MD: Paul H. Brookes.

Fox, L., Hemmeter, M. L., Snyder, P., Binder, D. P., \& Clarke, S. (2011). Coaching early childhood special educators to implement a comprehensive model for promoting young children's social competence. Topics in Early Childhood Special Education, 31(3), 178-192. https://doi.org/10.1177/0271121411404440

Fullerton, E. K., Conroy, M. A., \& Correa, V. I. (2009). Early childhood teachers' use of specific praise statements with young children at risk for behavioral disorders. Behavioral Disorders, 34(3), 118-135. https://doi.org/10.1177/019874290903400302

Gizir, Z. (2002). Anaokuluna devam eden dört-beş yas çocuklarında sosyal davranışların gelişimi ile benlik saygısı arasında ilişkinin incelenmesi (Yüksek lisans tezi), Ankara Üniversitesi, Ankara.

Hemmeter, M. L. \& Fox, L. (2009). The teaching pyramid: A model for the implementation of classroom practices within a program-wide approach to behavior support. National Head Start Association Dialog, 12(2), 133-147. https://doi.org/10.1080/15240750902774718

Hemmeter, M. L., Fox, L., \& Snyder, P. (2008a). Teaching Pyramid Observation Tool-research edition (Unpublished assessment instrument). Vanderbilt University, Nashville, TN.

Hemmeter, M. L., Fox, L., \& Snyder, P. (2008b). Class-Wide Challenging Behavior Observation Tool (Instrument and manual in preparation).

Hemmeter, M. L., Fox, L., \& Snyder, P., (2013). A tiered model for promoting social-emotional competence and addressing challenging behavior. V. Buysse \& E. Peisner-Feinberg (Eds.), Handbook of response to intervention in early childhood (s. 85-101) içinde. Baltimore, MD: Brookes.

Hemmeter, M. L., Hardy, J. K., Schnitz, A. G., Adams, J. M., \& Kinder, K. A. (2015). Effects of training and coaching with performance feedback on teachers' use of Pyramid Model practices. Topics in Early Childhood Special Education, 35(3), 144-156. https://doi.org/10.1177/0271121415594924

Hemmeter, M. L., Ostrosky, M., \& Fox, L. (2006). Social and emotional foundations for early learning: A conceptual model for intervention. School Psychology Review, 35(4), 583. https://doi.org/10.1080/02796015.2006.12087963

Hemmeter, M. L., Snyder, P. A., Fox, L., \& Algina, J. (2016). Evaluating the implementation of the Pyramid Model for promoting social-emotional competence in early childhood classrooms. Topics in Early Childhood Special Education, 36(3), 133-146. https://doi.org/10.1177/0271121416653386

Heo, K. H., Cheatham, G. A., Hemmeter, M. L., \& Noh, J. (2014). Korean early childhood educators' perceptions of importance and implementation of strategies to address young children's social-emotional competence. Journal of Early Intervention, 36(1), 49-66. https://doi.org/10.1177/1053815114557280

Hollingsworth, H. L., \& Winter, M. K. (2013). Teacher beliefs and practices relating to development in preschool: Importance placed on social-emotional behaviours and skills. Early Child Development and Care, 183(12), 1758-1781. https://doi.org/10.1080/03004430.2012.759567 
Kalkan, S. (2019). Sosyal-duygusal gelişimi risk altında olan okul öncesi çocuklarına yönelik Piramit Modeline dayalı uygulama temelli koçluk desteği içeren öğretmen mesleki gelişim programının etkililiği (Yayınlanmamış doktora tezi). Gazi Üniversitesi, Ankara.

Knott, D. (2004). Writing an annotated bibliography (based on materials originally developed for the equity studies program). New College Writing Centre. Erişim adresi: https://advice.writing.utoronto.ca/wpcontent/uploads/sites/2/annotated-bibliography.pdf

LaFreniere, P. J., \& Dumas, J. E. (1996). Social competence and behavior evaluation in children ages 3 to 6 years: The short from (SCBE-30). Psychological Assessment, 4, 369-377. https://doi.org/10.1037/1040-3590.8.4.369

Lam, L. T. \& Wong, E. M. (2017). Enhancing social-emotional well-being in young children through improving teachers' social-emotional competence and curriculum design in Hong Kong. International Journal of Child Care and Education Policy, 11(5), 1-14. https://doi.org/10.1186/s40723-017-0031-0

Linder, S. M., Rembert, K., Simpson, A., \& Ramey, M. D. (2016). A mixed-methods investigation of early childhood professional development for providers and recipients in the United States. Professional Development in Education, 42(1), 123-149. https://doi.org/10.1080/19415257.2014.978483

Luo, L., Snyder, P., Clark, C. L., \& Hong, X. (2017). Preschool teachers' use of Pyramid Model practices in Mainland China. Infants and Young Children, 30(3), 221-237. https://doi.org/10.1097/IYC.0000000000000096

Lynch, S. A. \& Simpson, C. G. (2010). Social skills: Laying the foundation for success. Dimensions of Early Childhood, 38(2), 3-12.

Meadan, H. \& Jegatheesan, B. (2010). Classroom pets and young children. Young Children, 65(3), 70-77.

Ocak, Ş. \& Arda, T. B. (2014). Okul öncesi dönemde önleyici müdahale edici programların karşılaştırılması. Hacettepe Üniversitesi Ĕ̆itim Fakültesi Dergisi, 29(4), 171-188.

Ocak, Ş. (2011). Önleyici Müdahale programlarında tartışılmakta olan unsurlar. Kuram ve Uygulamada Eğitim Bilimleri Dergisi, 11(3), 1375-1402.

Ostrosky, M. M. \& Meadan, H. (2010). Helping children play and learn together. Young Children, 65(1), 104110.

Parlak-Rakap, A. (2011). In-service early childhood teachers' perceptions about their roles in the development of selfdiscipline in children (Unpublished doctoral dissertation). Middle East Technical University, Ankara.

Powell, D. R., \& Diamond, K. E. (2013). Studying the implementation of coaching-based professional development. T. Halle, A. Metz, \& I. Martinez-Beck (Eds.), Applying implementation science in early childhood programs and systems (s. 97-116) içinde. Paul H Brookes Publishing Co.

Rakap, S. \& Kalkan, S. (2018, March). Bir mesleki gelişim yaklaşımı olarak uygulama temelli koçluk. 2. Uluslararası Erken Çocuklukta Müdahale Kongresi, Antalya.

Rakap, S. (2017). Impact of coaching on pre-service teachers' use of embedded instruction in inclusive preschool classrooms. Journal of Teacher Education, 68(2), 125-139. https://doi.org/10.1177/0022487116685753

Rakap, S., Balıkcı, S., \& Vural-Batık, M. (2015). Uygulama temelli koçluk el kitabı. Yayınlanmamış Mesleki Gelişim Materyali. Samsun: Ondokuz Mayıs Üniversitesi.

Rakap, S., Balikci, S., Kalkan, S., \& Aydin, B. (2018). Preschool teachers' use of strategies to support socialemotional competence in young children. International Journal of Early Childhood Special Education, 10(1), 11-25. doi: 10.20489/intjecse.454103

Rakap, S., Kalkan, S., Balikci, S., \& Aydin, B. (2018, May). Impact of training plus implementation support on preschool teachers' use of naturalistic instruction. 44th Annual Convention of Association for Behavior Analysis International, San Diego, California. 
Richardson-Gibbs, A. M., \& Klein, M. D. (2014). Making preschool inclusion work: Strategies for supporting children, teachers, and programs. London: Paul H. Brookes Publishing Company.

Sailor, W., Dunlap, G., Sugai, G., \& Horner, R. (Eds.). (2009). Handbook of positive behavior support. New York: Springer.

Senemoğlu, N. (2018). Gelişim öğrenme ve öğretim: Kuramdan uygulamaya (26. bs). Ankara: Anı Yayıncılık.

Snyder, P. \& Wolfe, B. (2008). The big three process components in early childhood professional development: Needs assessment, follow-up, and evaluation. P. Winton, J. McCollum ve C. Catlett (Ed.), Practical approaches to early childhood professional development: Evidence, strategies, and resources (s. 13-51) içinde. Washington, DC: Zero to Three.

Snyder, P., Hemmeter, M. L., Artman, K., Kinder, K., Pasia, C., \& McLaughlin, T. (2012). Characterizing key features of the early childhood professional development literature. Infants and Young Children, 25(3), 188212. doi: 10.1097/IYC.0b013e31825a1ebf

Snyder, P., Hemmeter, M. L., McLean, M., Sandall, S., McLaughlin, T., \& Algina, J. (2018). Effects of professional development on preschool teachers' use of embedded instruction practices. Exceptional Children, 84(2), 213-232. https://doi.org/10.1177/0014402917735512

Steed, E. A. \& Roach, A. T. (2017). Childcare providers' use of practices to promote young children's socialemotional competence. Infants ve Young Children, 30(2), 162-171. doi: 10.1097/IYC.0000000000000092

Steed, E.A., T.M. Pomerleau, \& R.H. Horner. (2012). Preschool-Wide Evaluation Tool (PreSET) Research Edition: An Assessment of Universal Program-Wide Positive Behavior Support in Early Childhood. CD-ROM ed. Brookes

Waltz, M. (2013). The importance of social and emotional development in young children. https://childrensacademyonline.net/wpcontent/uploads/2013/01/Importanceof-SEL-In-Early-ChildhoodDevt.pdf, sayfasından erişilmiştir.

Webster-Stratton, C. \& Reid, M. J. (2003). Treating conduct problems and strengthening social and emotional competence in young children: The dinosaur treatment program. Journal of Emotional and Behavioral Disorders, 11(3), 130-143. https://doi.org/10.1177/10634266030110030101

Yükseköğretim Kurulu Başkanlığı. (2018). Yeni öğretmen yetiştirme lisans programları: Okulöncesi öğretmenliği lisans programları. Ankara: Yükseköğretim Kurulu Başkanlığı. 


\section{EXTENDED ABSTRACT}

\section{Introduction}

It is very important that intervention programs developed to support social-emotional development of young children and to address their challenging behaviors include both preventive and remedial strategies (Durlak and DuPre, 2008; Ocak and Arda, 2014; Webster-Stratton and Reid, 2010). One of the programs that include preventive and remedial strategies is the Pyramid Model (Fox and Hemmeter, 2009; Hemmeter et al., 2006). Although there are many studies in the literature describing the key components of the Pyramid Model, examining teachers' use of Pyramid Model strategies, and investigating effectiveness of intervention programs developed based on this model, there is no study in the literature to our knowledge that reviews experimental and descriptive studies based on different variables. This study aims to present a review and annotated bibliography of experimental studies examining the effectiveness of intervention programs developed based on the Pyramid Model to support the social-emotional development and prevent challenging behaviors of preschool children and descriptive studies investigating preschool teachers' use of Pyramid Model strategies.

\section{Method}

This study used a qualitative approach to review experimental and descriptive studies focused on Pyramid Model practices. Following a description of literature search, screening for inclusion and coding qualifying articles, a narrative review and annotated bibliography of identified studies are presented.

\section{Results}

The annotated bibliography of each study included in this review is presented in three sections: (a) group experimental studies, (b) single-case experimental research studies, and (c) descriptive studies. Three group experimental studies conducted in the United States and Hong Kong were identified. Hemmeter et al. (2016) examined the impact of a professional development (PD) program (workshops and coaching) on preschool teachers' use of the Pyramid Model strategies and children' social-emotional skills and challenging behaviors, using a randomized controlled design. Findings showed that teachers in the experimental group significantly improved their use of Pyramid Model strategies in compassion to control group teachers. Fettig and ArtmanMeeker (2016) provided preliminary evidence for the effects of group coaching on preschool teachers' use of Pyramid Model strategies. Findings showed that the group coaching was effective in increasing teachers' implementation of the Pyramid Model practices. Lam and Wong (2017) investigated the effect of an intervention program focused on Pyramid model practices on social-emotional well-being of kindergarten children through improving teaching competence of kindergarten teachers in relation to social-emotional development. Results showed that there was a statistically significant improvement in the social-emotional development and a significant decrease in the anxiety levels and aggressive behaviors of the children after the intervention.

Three single-case experimental research studies conducted in the United States were identified. Fox et al. (2011) examined the effects of a multi-component PD program that included training, practice guides, class materials, and coaching, and focused on teaching Pyramid Model practices, on preschool teachers' use of Pyramid Model practices. Findings showed that the PD program including training and coaching support was effective in increasing teachers' use if Pyramid Model strategies. Artman-Meeker and Hemmeter (2013) investigated the effects of in-service training with performance feedback on preschool teachers' use of preventive practices (i.e., transition preparations, rule reminders, and social-emotional teaching strategies) associated with Pyramid Model. Findings revealed that the performance feedback presented via e-mail together with the training was effective in improving teachers' use of strategies. Hemmeter et al. (2015) investigated the impact of a PD intervention including training and coaching with performance feedback on preschool teachers' use of practices associated with the Pyramid Model. Findings showed that training and coaching with performance feedback was effective in helping teachers acquire practices and maintain them after the coaching support ended.

Four descriptive studies conducted in South Korea, the United States, China, and Turkey were identified. 
Heo et al. (2014) investigated Korean early childhood educators' perspectives and strategies to support socialemotional development in young children and to address their challenging behaviors. Findings revealed that most teachers believed in the importance of using strategies to support social-emotional development in young children, but they implemented strategies at low levels. Luo et al. (2017) investigated Chinese preschool teachers' implementation of practices associated with the Pyramid Model. Findings showed that teachers used approximately $31 \%$ of the practices associated with the Pyramid Model. Steed and Roach (2017) investigated childcare providers' use of social-emotional teaching practices associated with Pyramid Model in the United States. Findings showed that teachers use very few strategies to support social-emotional development of young children without any training. Rakap et al. (2018) examined Turkish preschool teachers' use of Pyramid model practices to support social-emotional development and prevent challenging behaviors of preschool children. Findings showed that preschool teachers used 14\% practices associated with the Pyramid Model, on average to support social-emotional competence of young children and to address their challenging behaviors.

\section{Conclusion}

Results of studies examined in this review show that the effectiveness of professional development programs that aim to teach teachers scientifically based or effective methods and strategies is directly linked with the strategies used during planning and implementation stages of these program. For this reason, professional development programs offered to teachers should support the implementation performance of teachers. In addition, it is recommended that the practices to support social-emotional development in young children should be an integral part of pre-service training efforts as gaining these skills is critically important in children's development. 